\title{
Pharmacokinetics, tissue distribution, and excretion of zinc oxide nanoparticles
}

This article was published in the following Dove Press journal:

International Journal of Nanomedicine

25 June 2012

Number of times this article has been viewed

\author{
Miri Baek',* \\ Hae-Eun Chung',* \\ Jin $\mathrm{Yu}^{1}, *$ \\ Jung-A Lee' \\ Tae-Hyun Kim² \\ Jae-Min $\mathrm{Oh}^{2}$ \\ Won-Jae Lee $^{3}$ \\ Seung-Min Paek ${ }^{3}$ \\ Jong Kwon $\mathrm{Lee}^{4}$ \\ Jayoung Jeong ${ }^{4}$ \\ Jin-Ho Choy ${ }^{5}$ \\ Soo-Jin Choi'
}

'Department of Food Science and Technology, Seoul Women's University,

Seoul, '2Department of Chemistry and

Medical Chemistry, College of Science

and Technology, Yonsei University,

Wonju, Gangwondo; ${ }^{3}$ Department of

Chemistry and Green-Nano Materials

Research Center, Kyungpook National

University, Taegu, ${ }^{4}$ Toxicological

Research Division, National Institute

of Food and Drug Safety Evaluation,

Chungchungbuk-do, ${ }^{5} \mathrm{Center}$ for

Intelligent Nano-Bio Materials,

Department of Bioinspired Science

and Department of Chemistry

and Nano Science, Ewha Womans

University, Seoul, Republic of Korea

*These authors contributed equally to this work

Correspondence: Soo-Jin Choi

126 Gongneung 2-dong, Nowon-gu,

Seoul 139-774, Republic of Korea

Tel +8 229705634

Fax +8 229705977

Email sjchoi@swu.ac.kr

Jin-Ho Choy

I I-I Daehyun-dong, Seodaemun-gu,

Seoul 120-750, Republic of Korea

$\mathrm{Tel}+82232774135$

Fax +82 232774340

Email jhchoy@ewha.ac.kr
Background: This study explored the pharmacokinetics, tissue distribution, and excretion profile of zinc oxide $(\mathrm{ZnO})$ nanoparticles with respect to their particle size in rats.

Methods: Two $\mathrm{ZnO}$ nanoparticles of different size $(20 \mathrm{~nm}$ and $70 \mathrm{~nm})$ were orally administered to male and female rats, respectively. The area under the plasma concentration-time curve, tissue distribution, excretion, and the fate of the nanoparticles in organs were analyzed.

Results: The plasma zinc concentration of both sizes of $\mathrm{ZnO}$ nanoparticles increased during the 24 hours after administration in a dose-dependent manner. They were mainly distributed to organs such as the liver, lung, and kidney within 72 hours without any significant difference being found according to particle size or rat gender. Elimination kinetics showed that a small amount of $\mathrm{ZnO}$ nanoparticles was excreted via the urine, while most of nanoparticles were excreted via the feces. Transmission electron microscopy and x-ray absorption spectroscopy studies in the tissues showed no noticeable $\mathrm{ZnO}$ nanoparticles, while new $\mathrm{Zn}-\mathrm{S}$ bonds were observed in tissues.

Conclusion: $\mathrm{ZnO}$ nanoparticles of different size were not easily absorbed into the bloodstream via the gastrointestinal tract after a single oral dose. The liver, lung, and kidney could be possible target organs for accumulation and toxicity of $\mathrm{ZnO}$ nanoparticles was independent of particle size or gender. $\mathrm{ZnO}$ nanoparticles appear to be absorbed in the organs in an ionic form rather than in a particulate form due to newly formed $\mathrm{Zn}-\mathrm{S}$ bonds. The nanoparticles were mainly excreted via the feces, and smaller particles were cleared more rapidly than the larger ones. $\mathrm{ZnO}$ nanoparticles at a concentration below $300 \mathrm{mg} / \mathrm{kg}$ were distributed in tissues and excreted within 24 hours. These findings provide crucial information on possible acute and chronic toxicity of $\mathrm{ZnO}$ nanoparticles in potential target organs.

Keywords: $\mathrm{ZnO}$ nanoparticles, pharmacokinetics, tissue distribution, excretion, fate

\section{Introduction}

Zinc oxide $(\mathrm{ZnO})$ is one of the most commonly utilized materials in diverse industrial fields such as dyes, paints, pigments, metallurgy additives, rubber, alloys, ceramics, chemical fibers, electronics, catalyst, medical diagnosis, sunscreens, cosmetics, personal care products, and food additives..$^{1-3}$ The wide range of applications of $\mathrm{ZnO}$ is attributed to their unique characteristics, including semiconducting, electrical, optical, catalytic, magnetic, antimicrobial and ultraviolet light absorption properties..$^{3-6}$ Recently, rapid advances in nanotechnology have contributed to manufacture and control of engineered nanoparticles, which are generally defined as particles in the size range of 1-100 nm in one dimension. To date, a great deal of attention has been focused on nanosized $\mathrm{ZnO}$ particles because they possess unique features, which are completely different from bulk-sized $\mathrm{ZnO}$ nanoparticles. As the particle size of $\mathrm{ZnO}$ 
decreases, its chemical reactivity, transparency, ultravioletfiltering efficiency, and dispersion properties also increase, which are favorable features for commercial application. ${ }^{7,8}$

However, study of the toxicological effects of $\mathrm{ZnO}$ nanoparticles in biological systems has lagged behind the speed of their mass production and applications in various fields. Furthermore, $\mathrm{ZnO}$ is generally considered to be a material with low toxicity, because zinc is an essential trace element in the human body and is commonly present in foods or added as a nutritional supplement, so zinc attracts little attention during assessment of toxicity of nanoparticles. ${ }^{9}$ It should be noted that small-sized particles have a higher proportion of atoms on their surfaces than do bulk-sized particles, so the former is more reactive and responsive than the latter. However, this raises concern about the possible biological activity of nanosized particles that may behave differently from their bulk-sized counterparts, which may have an adverse effect by interfering with biological functions, presumably due to their large surface area and enhanced reactivity. ${ }^{10}$

Along with extensive application of $\mathrm{ZnO}$ nanoparticles in the industrial field, it is conceivable that the human body may be intentionally or unintentionally exposed to nanoparticles via several possible routes, including oral ingestion, inhalation, intravenous injection, and dermal penetration. Among these, uptake of nanoparticles by the gastrointestinal tract is one of the most important routes. ${ }^{11}$ To date, almost all in vivo studies of the toxicity of nanoparticles have been focused on acute toxicity or repeated-dose toxicity evaluation via different routes. ${ }^{9,12-15}$ A few studies have investigated the pharmacokinetics of nanoparticles in whole animals, including absorption, distribution, metabolism, and excretion patterns at the systemic level. Pharmacokinetic study includes the evaluation of accumulating or remaining nanoparticle concentrations in all major tissues after exposure for a certain period of time until all nanoparticles are eliminated. ${ }^{16}$ Thus, pharmacokinetic study of nanoparticles is of importance in the context of understanding the amount absorbed which enters the systemic circulation and the kinetic profile of clearance by the excretory system following exposure, thus providing clues for the underlying debate on the safety of nanoparticles. Such research can also identify potential target organs for accumulation of $\mathrm{ZnO}$ nanoparticles, providing a further tool for investigating toxicity and its mechanism in vivo. To the best of our knowledge, no information is currently available on the pharmacokinetics of $\mathrm{ZnO}$ nanoparticles.

The pharmacokinetic profile, biological response, and toxicity of nanoparticles are also strongly affected by their physicochemical properties, such as particle size, surface area, surface chemistry, chemical composition, and stability. One of the critical factors for toxicity is the size of nanoparticles. ${ }^{17}$ Indeed, recent studies have been focused on the relationship between the size of $\mathrm{ZnO}$ nanoparticles and their toxicological effects. ${ }^{9,12,13,18-20}$ However, most studies have focused on comparing the toxic effects of nanosized particles with those of micron-sized ones, providing less information about toxicity per se, particularly for nanoparticles below $100 \mathrm{~nm}$. Moreover, many researchers have published toxicity data only from in vitro studies, so the impact of particle size on systemic toxicity in vivo remains to be clarified.

This paper describes a series of pharmacokinetic, biodistribution, and elimination studies on $\mathrm{ZnO}$ nanoparticles of two different sizes (20 nm and $70 \mathrm{~nm}$ ) after oral administration to male and female rats, in an attempt to identify the potential target organs relevant for a safety evaluation as well as mechanistic investigation, and to predict any potential harmful effects in the human body. Moreover, their fates in tissues following oral administration, determined by $\mathrm{x}$-ray absorption spectroscopy (XAS) and transmission electron microscopy (TEM), are reported in order to offer new insights into the absorption and distribution of $\mathrm{ZnO}$ nanoparticles in target organs.

\section{Materials and methods Preparation of nanoparticle suspension}

$\mathrm{ZnO}$ particles $20 \mathrm{~nm}$ and $70 \mathrm{~nm}$ in size were purchased from Sumitomo (Tokyo, Japan) and American Elements (Los Angeles, CA), respectively. For oral administration of $\mathrm{ZnO}$ nanoparticles with a negative surface charge, the nanoparticles were suspended in $20 \mathrm{mM}$ HEPES buffer containing $1 \%$ sodium citrate and then dispersed by vortexing for one minute. The final $\mathrm{pH}$ of the suspension was 7.3 , and $20 \%$ of the surface-modified $\mathrm{ZnO}$ nanoparticles were used as a stock solution. Before administration, the suspension was vortexed for 10 seconds and then diluted with distilled water.

\section{Characterization of nanoparticles}

Powder x-ray diffraction (XRD) patterns for the $\mathrm{ZnO}$ nanoparticles, both surface-modified and unmodified, were measured using an x-ray diffractometer (D2phaser, Bruker AXS Inc, Madison, WI) with Ni-filtered $\mathrm{CuK} \alpha$ radiation. Particle size was determined by scanning electron microscopy (SEM: Hitachi S-4300, Tokyo, Japan) and TEM (JEM-1010, JEOL, Tokyo, Japan). 
The surface charge (zeta potential) of the $\mathrm{ZnO}$ nanoparticles was determined using a zeta potentiometer (Zetasizer Nano ZS system, Malvern Instruments, Worcestershire, UK).

\section{Animals}

Five-week-old male and female Sprague-Dawley rats weighing 120-140 g were purchased from G-Bio (Seoul, South Korea). The animals were housed in plastic laboratory animal cages in a ventilated room. The room was maintained at $20^{\circ} \mathrm{C} \pm 2^{\circ} \mathrm{C}$ and $60 \% \pm 10 \%$ relative humidity on a 12-hour light/dark cycle. Water and commercial laboratory complete food for rats were available ad libitum. They were acclimatized to this environment for 7 days before receiving experimental treatment. All animal experiments were performed in compliance with the animal and ethics review committee of the Seoul Women's University.

\section{Dosing and sample collection}

Three groups of male and female rats $(\mathrm{n}=6$ per group) received a single dose of 50,300 , or $2000 \mathrm{mg} / \mathrm{kg}$ of $\mathrm{ZnO}$ nanoparticles by oral gavage, and one additional group of six rats received an equivalent volume of citrate/HEPES buffer as controls for all the experiments. Changes in body weight and behavior, and possible appearance of symptoms in the rats were carefully recorded every day after administration of the $\mathrm{ZnO}$ nanoparticles.

Blood samples were collected via the tail vein at several time points (time zero and hours $0.5,1,2,4,6,10,24,48$, 72, and 96) after oral administration to evaluate the plasma $\mathrm{ZnO}$ nanoparticle concentration. The blood samples were centrifuged at 3000 rpm for 15 minutes at $4^{\circ} \mathrm{C}$ to obtain the plasma. Several pharmacokinetic parameters were estimated using the Kinetica program (version 4.4, Thermo Electron Corporation, Waltham, MA), ie, maximum concentration $\left(\mathrm{C}_{\max }\right)$, time to maximum concentration $\left(\mathrm{T}_{\max }\right)$, area under the plasma concentration-time curve (AUC), half-life $\left(\mathrm{T}_{1 / 2}\right)$, and mean residence time (MRT).

For the tissue distribution study, tissue samples of the brain, heart, kidney, liver, lung, spleen, and testis or ovary were collected at designated times (hours 1 and 6 , and days 1 , 2,3 , and 7) following euthanasia by $\mathrm{CO}_{2}$. To evaluate the excretion profile, urine and feces were collected using a metabolic cage at hours 4 and 10, and at days 1, 2, 3, 4, 5, 6, $7,8,9,10$, and 14 after oral administration.

\section{Sample preparation for ICP-AES analysis} Homogenized biological samples ( $0.2 \mathrm{~g}$ of plasma, total amount of all tissues except liver, and $1 \mathrm{~g}$ of liver, urine, and feces) were predigested in $3-10 \mathrm{~mL}$ of ultrapure nitric acid overnight and heated at about $160^{\circ} \mathrm{C}$. Next, $0.5-1.0 \mathrm{~mL}$ of $\mathrm{H}_{2} \mathrm{O}_{2}$ was added according to the proportional weight of the samples. Each sample mixture was heated until completely digested. The remaining solution was then removed by heating until the solutions were colorless and clear. The solution were finally diluted to $5 \mathrm{~mL}$ with ultrapure water for the plasma sample and $10 \mathrm{~mL}$ for the other samples, and filtered at $0.45 \mu \mathrm{m}$. The total zinc content was determined using inductively coupled plasma-atomic emission spectroscopy (ICP-AES).

\section{Accuracy and quality control by ICP-AES analysis}

In addition to the control of chemical blanks, the zinc concentration in biological samples was checked accurately by assessing the matrix effects, in other words, by standard addition experiments and calculation of recovery, because any representative reference material is not commercially available for $\mathrm{ZnO}$ nanoparticles in biological samples. All the tissues, plasma, urine, and feces were spiked with known concentrations of standard zinc solution $(0,1,5,10,30$ and $80 \mu \mathrm{g} / \mathrm{mL}$, Sigma-Aldrich, St Louis, MO) which were also used for the external calibration. The same concentrations of standard $\mathrm{ZnO}$ nanoparticles $(20 \mathrm{~nm}$ and $70 \mathrm{~nm}$ ) were also added to reference biological samples for the spiking experiments prior to treatment and analysis of the samples, and finally, recovery was calculated.

\section{ICP-AES analysis}

Quantitative analysis was carried out using external five-point calibration with internal standard correction spiking experiments. Stock solutions were diluted with $20 \%$ ultrapure nitric acid to designated concentrations. Analysis of standards and biological samples was undertaken using ICP-AES (Jobin Yvon Horiba, JY 2000 Ultrace). The instrument operating conditions were as follows: RF power and nebulizer gas flow were set at $1000 \mathrm{~W}$ and $0.02 \mathrm{~mL}$ per minute of argon, respectively.

\section{TEM study}

Representative organs, including the liver and kidney, were collected from three male rats 24 hours after administration of $2000 \mathrm{mg} / \mathrm{kg}$ of $\mathrm{ZnO}$ nanoparticles. Three rats treated with citrate/HEPES buffer was used as controls. The samples were fixed with modified Karnovsky's fixative, ie, $2 \%$ paraformaldehyde and $2 \%$ glutaraldehyde in $0.05 \mathrm{M}$ sodium cacodylate buffer ( $\mathrm{pH}$ 7.2), post-fixed with 1:1 mixed solution of $2 \%$ osmium tetraoxide and $0.1 \mathrm{M}$ sodium cacodylate at $4{ }^{\circ} \mathrm{C}$ for 2 hours, and then stained with 
uranyl acetate. The samples were dehydrated with ethanol and subjected to block preparation with Spurr's resin. The blocks prepared were sectioned using an ultramicrotome (MT-X, RMC, Tucson, AZ). TEM images were observed using a Tecnai F20 instrument at the Korean Basic Science Institute, Gwangju Branch, Korea.

\section{XAS analysis}

XAS experiments at the $\mathrm{Zn} \mathrm{K}$ edge were performed using an extended $x$-ray absorption fine structure (EXAFS) facility installed at beamline $7 \mathrm{C}$ in the Pohang Accelerator Laboratory, Korea. Twenty-four hours after oral administration of $2000 \mathrm{mg} / \mathrm{kg}$ of the two different-sized $\mathrm{ZnO}$ nanoparticles to three male rats, their kidneys, livers, and spleens were collected. Three rats administered citrate/HEPES buffer were used as controls. All the freeze-dried and homogenized tissue samples and the reference $\mathrm{ZnO}$ nanoparticles for comparison were finely ground and packed into a cell $0.2 \mathrm{~mm}$ thick with Kapton tape. The XAS data were collected at room temperature in fluorescence mode to detect very small amounts of zinc species in the samples. All the spectra were calibrated by measuring the spectra of zinc metal foil simultaneously with those of the samples. The data analyses were conducted using a standard procedure, as described elsewhere. ${ }^{21}$ Briefly, the inherent background in the XAS data was removed by fitting a polynomial to the pre-edge region and extrapolating it through the entire spectrum, from which it was subtracted. Next, the resulting EXAFS raw data were Fourier-transformed to obtain the radial distribution function.

\section{Statistical analysis}

The data were expressed as the mean \pm standard deviation. For statistical analysis, the experimental values were compared with their corresponding controls. One-way analysis of variance in SAS software (Tukey's test, version 11.0, Cary, NC) was used to illustrate any statistically significant differences between the experimental group and the control group. Statistical significance for all tests was set at $P<0.05$.

\section{Results}

\section{Characterization of $\mathrm{ZnO}$ nanoparticles}

The pharmacokinetics of two different sizes of $\mathrm{ZnO}$ nanoparticles (20 $\mathrm{nm}$ and $70 \mathrm{~nm}$ ) were evaluated. The $\mathrm{ZnO}$ nanoparticles were capped with citrate molecules, widely used as capping agents, so had a negative surface charge as shown in Table 1. The surface charges for the citratemodified nanoparticles were measured at $-28.1 \mathrm{mV}$ for
Table I Particle size and zeta potential of $\mathrm{ZnO}$ nanoparticles

\begin{tabular}{|c|c|c|c|c|}
\hline & \multicolumn{2}{|c|}{$\begin{array}{l}\text { Measured particle } \\
\text { size }(\mathrm{nm})^{\mathrm{a}}\end{array}$} & \multicolumn{2}{|c|}{$\begin{array}{l}\text { Zeta potential } \\
(\mathrm{mV})\end{array}$} \\
\hline & Pristine & Citrate-modified & Pristine $^{b}$ & Citrate-modified \\
\hline $20 \mathrm{~nm}$ & $20 \pm 9$ & $21 \pm 6$ & 22.0 & -28.1 \\
\hline $70 \mathrm{~nm}$ & $67 \pm 12$ & $71 \pm 19$ & 19.6 & -33.3 \\
\hline
\end{tabular}

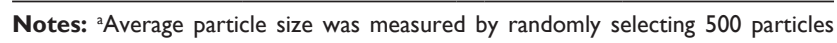
from transmission electron micrographs; 'beta potential was measured in distilled water ( $\mathrm{pH} 7.0)$.

the $20 \mathrm{~nm}$ size and $-33.3 \mathrm{mV}$ for the $70 \mathrm{~nm}$ size. SEM and TEM images indicated that they were spherical-shaped, with average diameters of $21 \pm 6 \mathrm{~nm}$ and $71 \pm 19 \mathrm{~nm}$, respectively, and had a narrow size distribution (Figure 1 and Table 1). XRD patterns for the $20 \mathrm{~nm}$ and $70 \mathrm{~nm} \mathrm{ZnO}$ nanoparticles, whether surface-modified or surface-unmodified showed peaks characteristic of those found in wurtzite-type $\mathrm{ZnO}$ structures (PCPDF 05-0664, Figure 1E). As expected from the particle size, $70 \mathrm{~nm} \mathrm{ZnO}$ was better crystallized than the $20 \mathrm{~nm}$ size, which was further confirmed by sharper powder XRD peaks. Upon citrate coating, no significant change in crystallinity was detected for either the $20 \mathrm{~nm}$ or the $70 \mathrm{~nm}$ $\mathrm{ZnO}$ nanoparticles.

\section{Effects of $\mathrm{ZnO}$ nanoparticles on body weight and symptoms}

After single-dose oral administration of the different sizes of $\mathrm{ZnO}$ nanoparticles, changes in body weight, mortality rate, behavior, and appearance of symptoms were observed for 14 days. The male and female rats administered low (50 mg/kg) and medium (300 mg/kg) doses of $\mathrm{ZnO}$ nanoparticles showed no mortality, body weight changes, or abnormal behavior when compared with the control group (Figure 2). On the other hand, slight loss of body weight and diarrhea were observed in some rats receiving high $(2000 \mathrm{mg} / \mathrm{kg})$ doses. However, no statistically significant difference in body weight was found between the controls and the groups administered either size of $\mathrm{ZnO}$ nanoparticles.

\section{Plasma concentration-time curve}

Plasma $\mathrm{ZnO}$ nanoparticle concentrations after oral administration to male or female rats were calculated by measuring the zinc level using ICP-AES, as shown in Figure 3. The plasma concentration-time curve was highly dependent on the dose administered. When $50 \mathrm{mg} / \mathrm{kg}$ of $20 \mathrm{~nm}$ particles were administered, the arithmetic mean plasma zinc concentration increased slightly at $0.5-2.0$ hours post-dosing, followed by decreases in plasma zinc levels. On the other hand, the highest plasma zinc levels were 
A

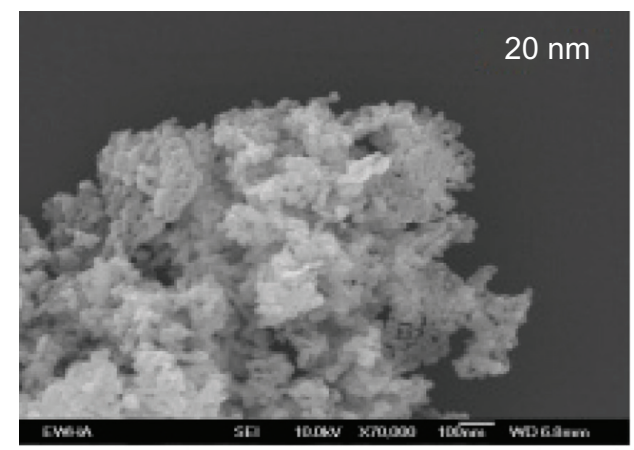

C

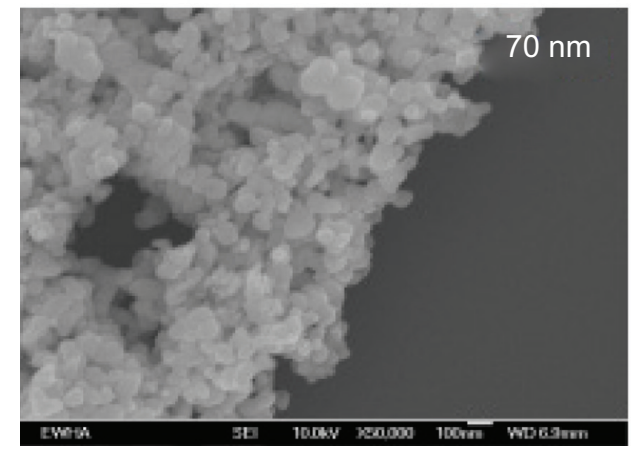

B

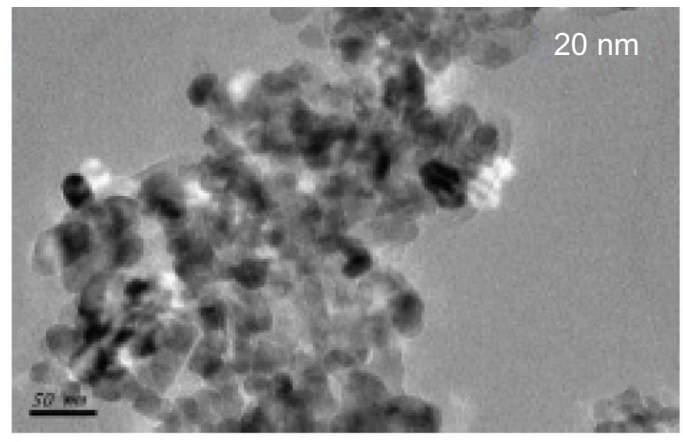

D

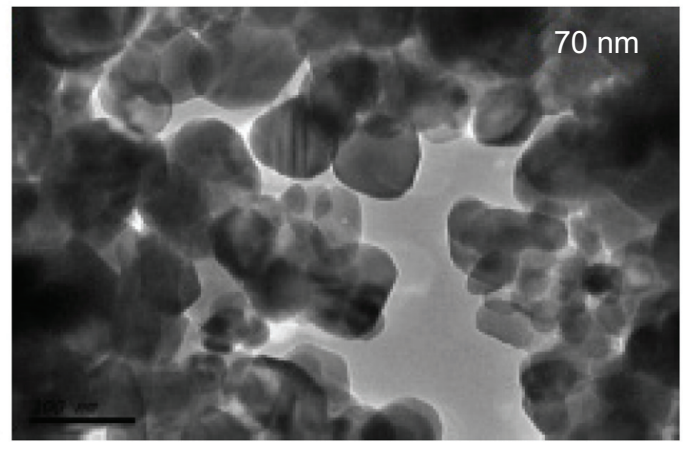

$\mathbf{E}$

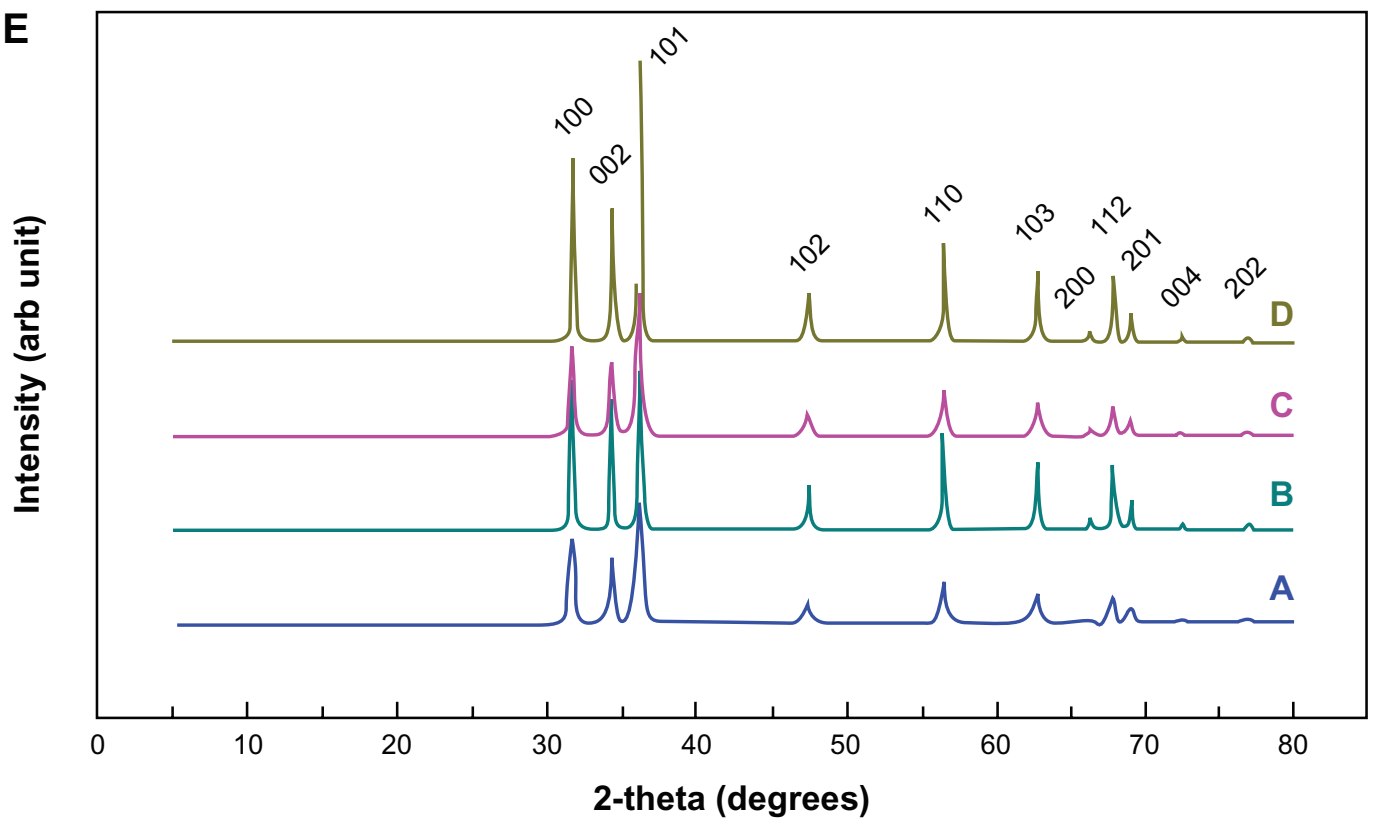

Figure I SEM (A and C) and TEM (B and D) images of $20 \mathrm{~nm}$ and $70 \mathrm{~nm} \mathrm{ZnO}$ nanoparticles, respectively. XRD patterns (E) for pristine $20 \mathrm{~nm}$ (A), pristine $70 \mathrm{~nm}$ (B), citrate-modified $20 \mathrm{~nm}(\mathbf{C})$, and citrate-modified $70 \mathrm{~nm}$ (D) nanoparticles.

observed at 6 and 24 hours in rats receiving the 300 and $2000 \mathrm{mg} / \mathrm{kg}$ doses, but decreased within 24 and 72 hours, respectively. Almost the same results were obtained in rats administered the $70 \mathrm{~nm}$ nanoparticles, showing peaks at hours 1,6 , and 24 for the 50,300 , and $2000 \mathrm{mg} / \mathrm{kg}$ doses, respectively.

The pharmacokinetic parameters following oral administration are presented in Table 2. All parameters increased as the dose administered increased. When the $\mathrm{T}_{\max }$ values for the
$20 \mathrm{~nm}$ and $70 \mathrm{~nm} \mathrm{ZnO}$ nanoparticles were compared, their value increased in a dose-dependent manner, but no correlation with particle size or gender was observed. Values of the other parameters, such as $\mathrm{C}_{\max }, \mathrm{AUC}, \mathrm{MRT}$, and $\mathrm{T}_{1 / 2}$, for the two different-sized nanoparticles were determined to be slightly greater for male rats than for female rats. When only the effect of particle size was compared, it was estimated that AUC and MRT values for the $20 \mathrm{~nm}$ nanoparticles were slightly higher than those for the $70 \mathrm{~nm}$ nanoparticles. There was no clear 

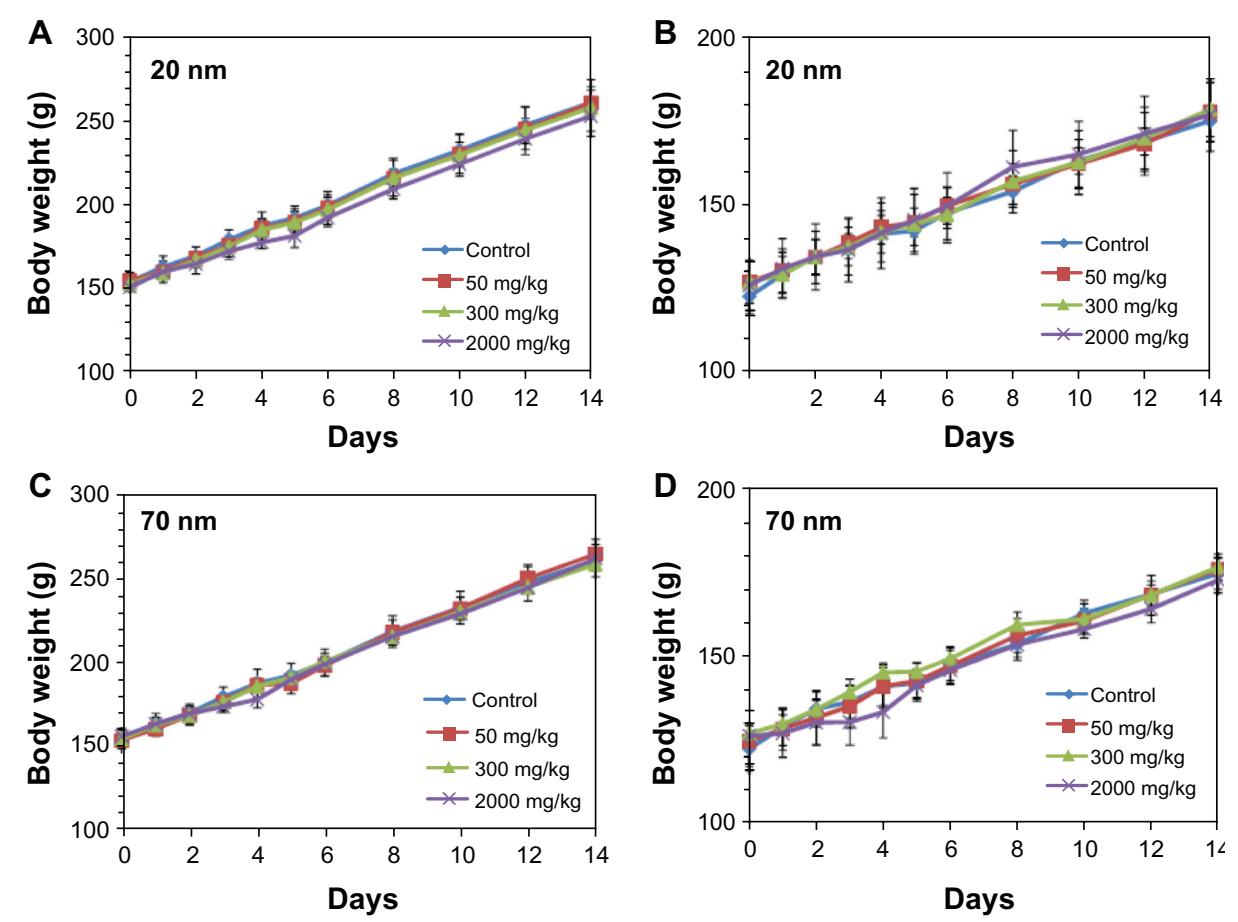

Figure 2 Body weight gain in male (A and $\mathbf{C})$ and female (B and $\mathbf{D})$ rats treated with $20 \mathrm{~nm}$ and $70 \mathrm{~nm} \mathrm{ZnO} \mathrm{nanoparticles,} \mathrm{respectively.}$ Note: The data show no significant difference from the control group $(P<0.05)$.

effect of particle size or gender on pharmacokinetics in any of the study groups.

Based on AUC values calculated from the increases in zinc levels, the total amount of $\mathrm{ZnO}$ nanoparticles in the blood circulation could be determined (Table 3). Absorption (\%) was calculated as follows. AUC values in the total volume of plasma were divided by the total amount of zinc administered (converted from $\mathrm{ZnO}$ dose). About 6.48\%-32.49\% of the total amount of administered $\mathrm{ZnO}$ nanoparticles was absorbed into the blood stream. As expected, the amount absorbed increased as the dose administered increased. In all the treatment groups, absorption of $\mathrm{ZnO}$ nanoparticles was slightly higher in male rats than in female rats, although this difference was not statistically significant. In terms of particle size, absorption for the $20 \mathrm{~nm}$ size nanoparticles was slightly higher than that for the $70 \mathrm{~nm}$ nanoparticles in all groups.

\section{Tissue distribution}

The tissue distribution of $\mathrm{ZnO}$ nanoparticles was determined in the brain, kidney, liver, lung, spleen, and ovary or testis by measuring the total zinc level with ICP-AES (Figure 4 and Supplementary Figure S1). When the concentrations of total zinc levels were compared between the experimental groups and the controls, no statistically significant increases were observed in the brain or spleen at all time points regardless of the nanoparticle size administered. When $50 \mathrm{mg} / \mathrm{kg}$ and $300 \mathrm{mg} / \mathrm{kg} \mathrm{ZnO}$ nanoparticle doses were administered, elevated zinc levels were observed in the liver, lung, and kidney in 6-24 hours, but returned to normal levels afterwards (Supplementary Figure S1). However, high accumulation of $\mathrm{ZnO}$ nanoparticles was evident in the liver and kidney within 2 and 3 days, respectively, when $2000 \mathrm{mg} / \mathrm{kg}$ of either $\mathrm{ZnO}$ nanoparticle size was administered, but were not detected at 7 days after administration (Figure 4). No remarkable difference in distribution in the liver and kidney was seen according to particle size or gender. In the lung, high amounts of $\mathrm{ZnO}$ nanoparticles of both sizes were found within 24 hours, especially at the $2000 \mathrm{mg} / \mathrm{kg}$ dose, but the elevated zinc level decreased after 2 days. In the reproductive system, zinc levels were elevated in the testis or ovary at one hour after administration in some cases (Figure 4 and Supplementary Figure S1). Twenty-four hours after administration, about $8.15 \%$ and $11.22 \%$ of $20 \mathrm{~nm} \mathrm{ZnO}$ nanoparticles were detected in the esophagus, stomach, and intestine in males and females, respectively, while $7.44 \%$ and $13.37 \%$ of the $70 \mathrm{~nm}$ particles were found in the digestive system in males and females, respectively. Less than $0.1 \%$ of $\mathrm{ZnO}$ nanoparticles were detected in these organs at 7 days after administration, regardless of size.

The total increase in tissue zinc levels is summarized in Table 4. Significantly elevated zinc levels were observed in the kidney, liver, and lung after administration of the 


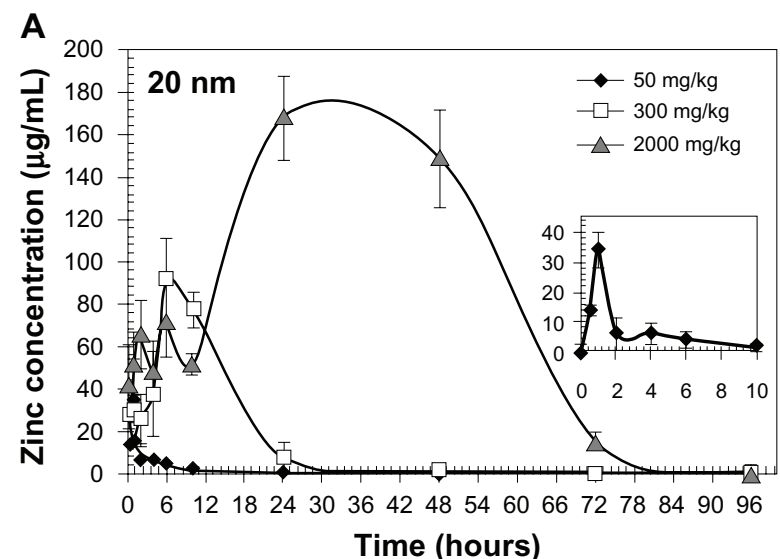

Time (hours)

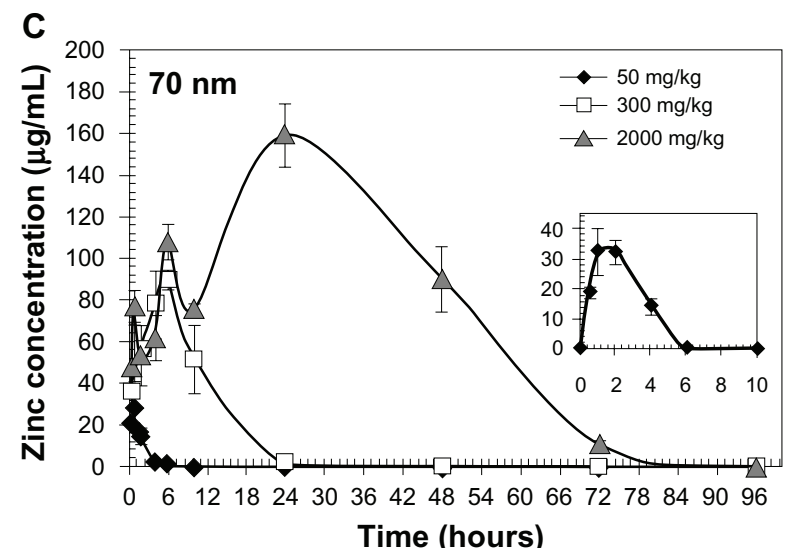

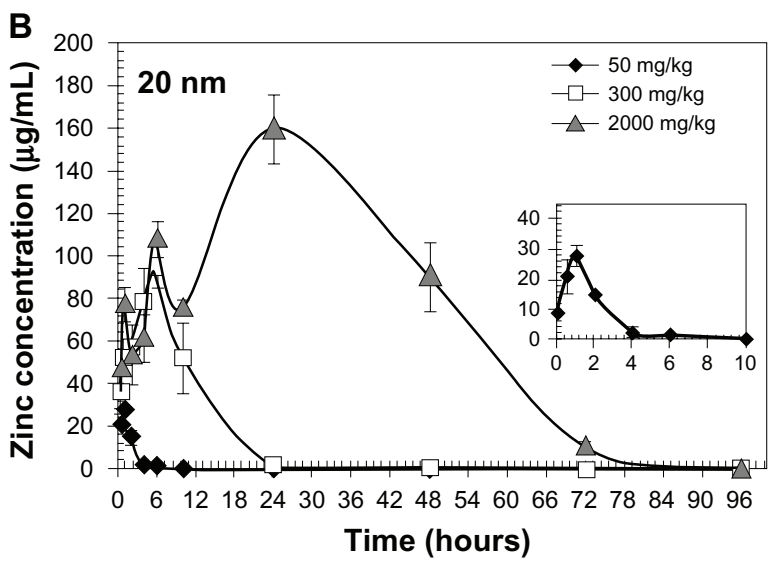

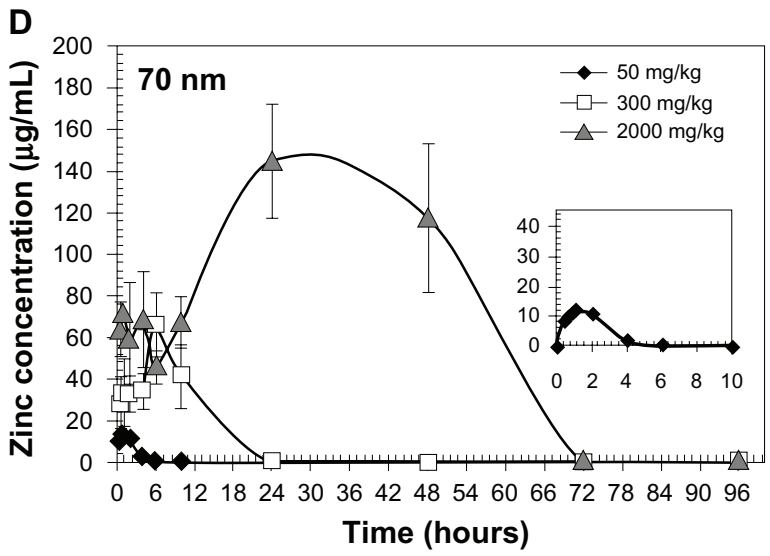

Figure 3 Plasma concentrations of $\mathrm{ZnO}$ nanoparticles after single-dose oral administration in male (A and $\mathbf{C})$ and female (B and $\mathbf{D})$ rats.

Notes: $\mathrm{ZnO}$ nanoparticle levels were measured by ICP-AES. The data are presented as increased zinc levels after subtraction of the basal zinc level in the control group. Insert: higher magnification of plasma concentration-time curve for the $50 \mathrm{mg} / \mathrm{kg}$ dose.

$2000 \mathrm{mg} / \mathrm{kg}$ dose compared with controls. A slightly higher amount of $\mathrm{ZnO}$ nanoparticles was detected in all organs in the male rats compared with that in the female rats, but the difference did not reach statistical significance. The difference in tissue $\mathrm{ZnO}$ nanoparticle distribution according to particle size was also not statistically significant.

\section{Fate of $\mathrm{ZnO}$ nanoparticles in tissues}

In order to evaluate and confirm the tissue accumulation and distribution of orally administered $\mathrm{ZnO}$ nanoparticles, we carried out TEM analysis on organs dissected from the rats administered $\mathrm{ZnO}$. A high dose of the two different sizes of $\mathrm{ZnO}$ nanoparticles was administered to ensure their

Table 2 Pharmacokinetic parameters of different-sized $\mathrm{ZnO}$ nanoparticles in rats

\begin{tabular}{|c|c|c|c|c|c|c|c|c|c|c|c|c|}
\hline & \multicolumn{4}{|c|}{50 mg/kg } & \multicolumn{4}{|c|}{$300 \mathrm{mg} / \mathrm{kg}$} & \multicolumn{4}{|c|}{$2000 \mathrm{mg} / \mathrm{kg}$} \\
\hline & \multicolumn{2}{|l|}{$20 \mathrm{~nm}$} & \multicolumn{2}{|l|}{$70 \mathrm{~nm}$} & \multicolumn{2}{|l|}{$20 \mathrm{~nm}$} & \multicolumn{2}{|l|}{$70 \mathrm{~nm}$} & \multicolumn{2}{|l|}{$20 \mathrm{~nm}$} & \multicolumn{2}{|l|}{$70 \mathrm{~nm}$} \\
\hline & Male & Female & Male & Female & Male & Female & Male & Female & Male & Female & Male & Female \\
\hline $\begin{array}{l}\mathrm{C}_{\max } \\
(\mu \mathrm{g} / \mathrm{mL})\end{array}$ & $\begin{array}{l}34.28 \pm \\
17.50^{\mathrm{a}}\end{array}$ & $\begin{array}{l}27.97 \pm \\
5.44^{\mathrm{ab}}\end{array}$ & $\begin{array}{l}35.17 \pm \\
6.99^{a}\end{array}$ & $\begin{array}{l}12.85 \pm \\
0.97^{b}\end{array}$ & $\begin{array}{l}94.544 \pm \\
17.16^{\mathrm{a}}\end{array}$ & $\begin{array}{l}91.56 \pm \\
3.18^{\mathrm{a}}\end{array}$ & $\begin{array}{l}84.19 \pm \\
4.92^{\mathrm{ab}}\end{array}$ & $\begin{array}{l}65.79 \pm \\
13.08^{b}\end{array}$ & $\begin{array}{l}179.53 \pm \\
12.62^{\mathrm{a}}\end{array}$ & $\begin{array}{l}159.43 \pm \\
15.54^{\mathrm{a}}\end{array}$ & $\begin{array}{l}180.9 \mid \pm \\
17.37^{a}\end{array}$ & $\begin{array}{l}|55.2| \pm \\
36.82^{\mathrm{a}}\end{array}$ \\
\hline $\begin{array}{l}T_{\max } \\
\text { (h) }\end{array}$ & I & I & I & I & 6 & 6 & 6 & 6 & 24 & 24 & 24 & 24 \\
\hline $\begin{array}{l}\text { AUC } \\
(h \times g / m L)\end{array}$ & $\begin{array}{l}105.32 \pm \\
16.26^{\mathrm{a}}\end{array}$ & $\begin{array}{l}59.01 \pm \\
10.1 I^{b}\end{array}$ & $\begin{array}{l}93.7 \pm \\
9.14^{\mathrm{a}}\end{array}$ & $\begin{array}{l}29.20 \pm \\
4.6 I^{c}\end{array}$ & $\begin{array}{l}1063.13 \pm \\
313.15^{\mathrm{a}}\end{array}$ & $\begin{array}{l}917.50 \pm \\
60.40^{\mathrm{a}}\end{array}$ & $\begin{array}{l}769.62 \pm \\
28.33^{\mathrm{ab}}\end{array}$ & $\begin{array}{l}558.35 \\
\pm 91.11^{b}\end{array}$ & $\begin{array}{l}7981.06 \pm \\
653.69^{\mathrm{a}}\end{array}$ & $\begin{array}{l}6645.12 \pm \\
473.98^{b}\end{array}$ & $\begin{array}{l}6934.87 \pm \\
664.07^{\mathrm{ab}}\end{array}$ & $\begin{array}{l}5883.28 \pm \\
848.58^{b}\end{array}$ \\
\hline $\begin{array}{l}\text { MRT } \\
\text { (h) }\end{array}$ & $\begin{array}{l}7.16 \pm \\
3.04^{\mathrm{a}}\end{array}$ & $\begin{array}{l}2.04 \pm \\
0.46^{b}\end{array}$ & $\begin{array}{l}3.34 \pm \\
0.24^{\mathrm{b}}\end{array}$ & $\begin{array}{l}1.86 \pm \\
0.21^{b}\end{array}$ & $\begin{array}{l}11.91 \pm \\
1.27^{\mathrm{a}}\end{array}$ & $\begin{array}{l}7.88 \pm \\
0.96^{c}\end{array}$ & $\begin{array}{l}9.60 \pm \\
0.19^{b}\end{array}$ & $\begin{array}{l}7.67 \pm \\
0.29 c\end{array}$ & $\begin{array}{l}39.19 \pm \\
0.73^{\mathrm{a}}\end{array}$ & $\begin{array}{l}36.53 \pm \\
0.56^{\mathrm{b}}\end{array}$ & $\begin{array}{l}32.30 \pm \\
0.81^{c}\end{array}$ & $\begin{array}{l}32.01 \pm \\
2.20^{c}\end{array}$ \\
\hline $\begin{array}{l}T_{1 / 2} \\
\text { (h) }\end{array}$ & $\begin{array}{l}5.06 \pm \\
2.00^{\mathrm{a}}\end{array}$ & $\begin{array}{l}1.21 \pm \\
0.40^{\mathrm{b}}\end{array}$ & $\begin{array}{l}1.84 \pm \\
0.16^{b}\end{array}$ & $\begin{array}{l}0.86 \pm \\
0.22^{b}\end{array}$ & $\begin{array}{l}8.11 \pm \\
1.31^{\mathrm{a}}\end{array}$ & $\begin{array}{l}6.77 \pm \\
0.53^{b}\end{array}$ & $\begin{array}{l}7.16 \pm \\
0.04^{\mathrm{ab}}\end{array}$ & $\begin{array}{l}6.91 \pm \\
0.21^{\mathrm{ab}}\end{array}$ & $\begin{array}{l}30.28 \pm \\
0.00^{\mathrm{a}}\end{array}$ & $\begin{array}{l}26.17 \pm \\
0.76^{b}\end{array}$ & $\begin{array}{l}26.99 \pm \\
0.52^{b}\end{array}$ & $\begin{array}{l}14.72 \pm \\
0.32^{c}\end{array}$ \\
\hline
\end{tabular}

Note: Statistical analysis was performed between four groups administered with the same dose.

Abbreviations: AUC, area under the concentration-time curve; MRT, mean residence time; $T_{1 / 2}$, elimination half-life; $C_{\max }$, maximum concentration; $T_{\max }$, time to peak plasma concentration. 
Table 3 Absorption of different-sized $\mathrm{ZnO}$ nanoparticles in rats

\begin{tabular}{|c|c|c|c|c|c|c|c|c|c|c|c|c|}
\hline & \multicolumn{4}{|c|}{$50 \mathrm{mg} / \mathrm{kg}$} & \multicolumn{4}{|c|}{$300 \mathrm{mg} / \mathrm{kg}$} & \multicolumn{4}{|c|}{$2000 \mathrm{mg} / \mathrm{kg}$} \\
\hline & \multicolumn{2}{|c|}{$20 \mathrm{~nm}$} & \multicolumn{2}{|c|}{$70 \mathrm{~nm}$} & \multicolumn{2}{|c|}{$20 \mathrm{~nm}$} & \multicolumn{2}{|c|}{$70 \mathrm{~nm}$} & \multicolumn{2}{|c|}{$20 \mathrm{~nm}$} & \multicolumn{2}{|c|}{$70 \mathrm{~nm}$} \\
\hline & Male & Female & Male & Female & Male & Female & Male & Female & Male & Female & Male & Female \\
\hline Absorption (\%)* & 17.55 & 11.35 & 15.62 & 5.62 & 29.53 & 29.41 & 21.38 & 17.90 & 33.25 & 31.95 & 28.90 & 28.29 \\
\hline
\end{tabular}

Note: *Absorption was calculated based on AUC values.

distribution in the liver and kidney, as shown in Figure 4 and Table 4. Accumulation, dissolution, and phase-transformation of the $\mathrm{ZnO}$ nanoparticles were captured in TEM images. As shown in Figure 5, all the TEM images of organs treated with $\mathrm{ZnO}$ nanoparticles looked similar to the control groups, and no $\mathrm{ZnO}$ nanoparticles were found.

We also examined the XAS of representative organ samples including from the liver, kidney, and spleen after oral administration, in comparison with the reference $\mathrm{ZnO}$ nanoparticles, because XAS analysis could provide useful information on the local structure around the zinc atoms in each organ. The XAS data for each organ using $\mathrm{ZnO}$ nanoparticles as a reference are shown in Figure 6. The radial distribution function was obtained by Fourier transformation of extended $\mathrm{x}$-ray absorption fine structure spectra. $\mathrm{ZnO}$ nanoparticles $20 \mathrm{~nm}$ in size showed well developed Fourier transform peaks at $1.5 \AA$ and $3.0 \AA$ in radial distribution function (nonphase shift-corrected), which can be attributed to the $\mathrm{Zn}-\mathrm{O}$ and $\mathrm{Zn}-\mathrm{Zn}$ bonds in the wurtzite structure, respectively. This finding is in good agreement with XRD data for the $\mathrm{ZnO}$ nanoparticles (Figure 1E).
In the radial distribution function of the liver sample after oral administration, two characteristic Fourier transform peaks were observed at around $1.5 \AA$ and $2.0 \AA$. The first and second peaks can be indexed to $\mathrm{Zn}-\mathrm{O}$ and $\mathrm{Zn}-\mathrm{S}$ bonds, respectively. The spectral features for the kidney sample were very similar to those observed in the liver sample, where the two Fourier transform peaks are attributed to $\mathrm{Zn}-\mathrm{O}$ and $\mathrm{Zn}-\mathrm{S}$ bonds. In the radial distribution function of the spleen, the first two peaks below $2.0 \AA$ and at $2.0 \AA$ are assigned as $\mathrm{Zn}-\mathrm{O}$ neighbors and $\mathrm{Zn}-\mathrm{S}$ bonds, respectively. It is noteworthy that the organ samples did not show the $\mathrm{Zn}-\mathrm{Zn}$ bonds which were clearly found in the reference $\mathrm{ZnO}$ nanoparticles. In the radial distribution function of all the biological samples, Fourier transform peaks observed above $2.5 \AA$ were from the background and/or multiple scatterings.

\section{Excretion}

The excretion profiles for the $\mathrm{ZnO}$ nanoparticles via urine and feces were studied by measuring total zinc levels on ICPAES, as shown in Figure 7. When $50 \mathrm{mg} / \mathrm{kg}$ and $300 \mathrm{mg} / \mathrm{kg}$
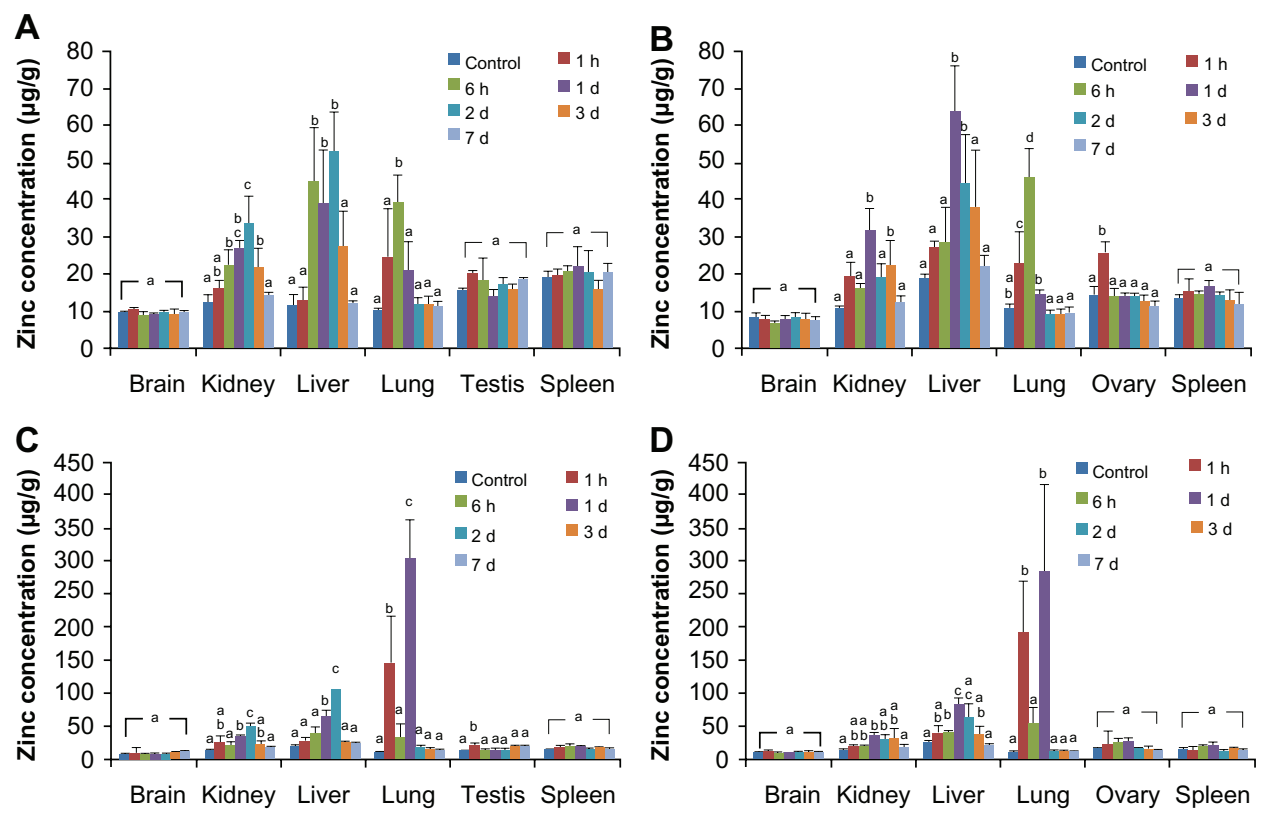

Figure 4 Tissue distribution of $\mathrm{ZnO}$ nanoparticles in rats after single-dose oral administration of $2000 \mathrm{mg} / \mathrm{kg} 20 \mathrm{~nm}$ and $70 \mathrm{~nm}$ in male (A and $\mathbf{C})$ and female (B and $\mathbf{D})$ rats, respectively. 


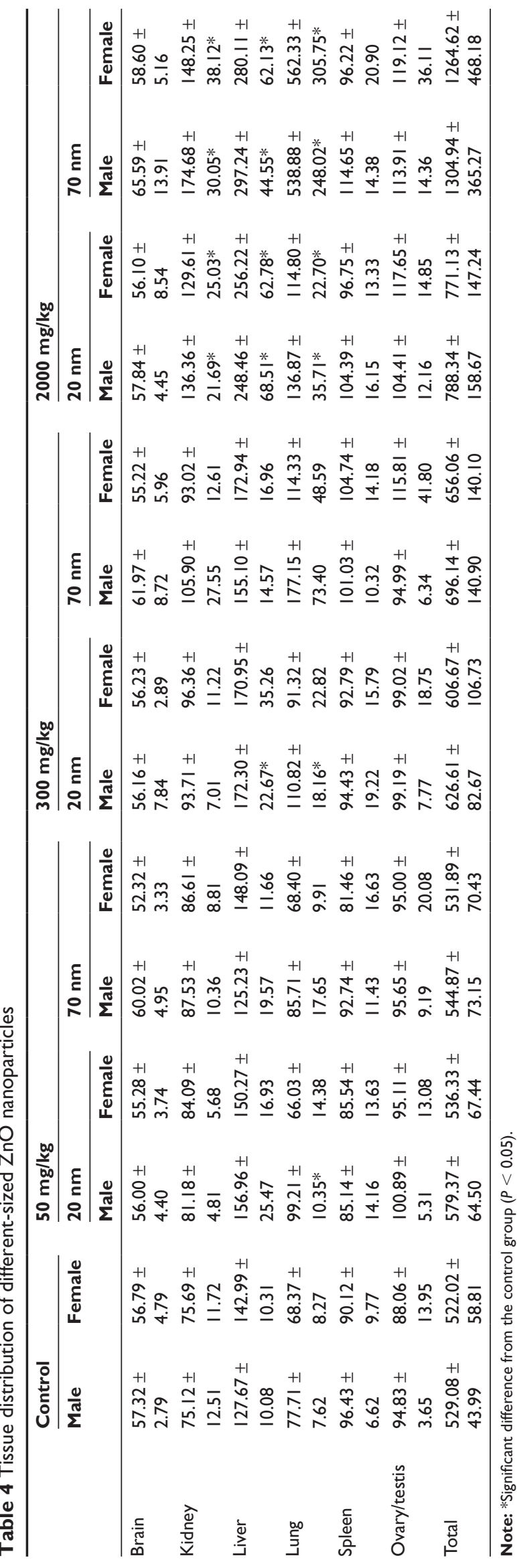

of $\mathrm{ZnO}$ nanoparticles were administered, elevated zinc levels were found in the urine 4-24 hours after oral treatment, followed by dramatic decreases in zinc levels in the samples. However, the highest zinc level was detected in the urine after 2-3 days, then gradually decreased at 6-7 days when $2000 \mathrm{mg} / \mathrm{kg}$ of the $20 \mathrm{~nm}$ and $70 \mathrm{~nm} \mathrm{ZnO}$ nanoparticles were administered, regardless of gender. On the other hand, a significant increase in zinc levels was observed in the feces 4-24 hours after treatment when $50 \mathrm{mg} / \mathrm{kg}$ and $300 \mathrm{mg} / \mathrm{kg}$ doses were administered. In rats treated with $2000 \mathrm{mg} / \mathrm{kg}$ of $20 \mathrm{~nm} \mathrm{ZnO}$ nanoparticles, a massive amount of zinc was detected primarily in the feces for 1-2 days after administration, while excretion via the feces continued for 3 days in rats administered a $2000 \mathrm{mg} / \mathrm{kg}$ dose of $70 \mathrm{~nm}$ $\mathrm{ZnO}$ nanoparticles.

Excretion values for $\mathrm{ZnO}$ nanoparticles based on these results are presented in Table 5. The percentage excretion was calculated by dividing the total increased zinc level in urine or feces by the total amount of administered zinc converted from the $\mathrm{ZnO}$ dose. Of the total amount of $\mathrm{ZnO}$ nanoparticles administered, $0.32 \%-1.47 \%$ was cleared via the urine, while most was excreted via the feces. The $\mathrm{ZnO}$ nanoparticle excretion rate via the urine decreased as the dose administered was increased, while excretion via the feces increased in a dose-dependent manner. Noteworthy is that a slightly higher rate of $\mathrm{ZnO}$ nanoparticle excretion via the urine was observed in male rats than in female rats, independent of particle size.

\section{Discussion}

This study describes the absorption, tissue distribution, and excretion of orally administered $\mathrm{ZnO}$ nanoparticles of two different sizes in male and female rats. $\mathrm{ZnO}$ nanoparticles sized $20 \mathrm{~nm}$ and $70 \mathrm{~nm}$ were selected because nanoparticles are generally defined as being in the size range of $1-100 \mathrm{~nm}$. The $\mathrm{ZnO}$ nanoparticles were capped with citrate to obtain nanoparticles with an evenly modified negatively charged surface, thereby minimizing the effect of surface charge on kinetic behavior. Citrate was also used to obtain a well dispersed suspension of $\mathrm{ZnO}$ nanoparticles for oral administration. ${ }^{22}$ It is well known that citrates and citric acid are important ligands for metal ions in biological systems, forming strong bonds with various ions, such as $\mathrm{Zn}^{2+}, \mathrm{Fe}^{3+}, \mathrm{Ca}^{2+}, \mathrm{Mg}^{2+}$ and $\mathrm{Ag}^{+} \cdot{ }^{23}$ In particular, citrate ions are characterized by three negatively charged centers under normal physiological conditions ( $\mathrm{pH}$ about 7.4), so zinc citrate complexes on the surfaces of the $\mathrm{ZnO}$ nanoparticles result in a negative surface charge, ${ }^{24}$ while the zeta potentials of the pristines in our study were slightly positive (Table 1 ). 

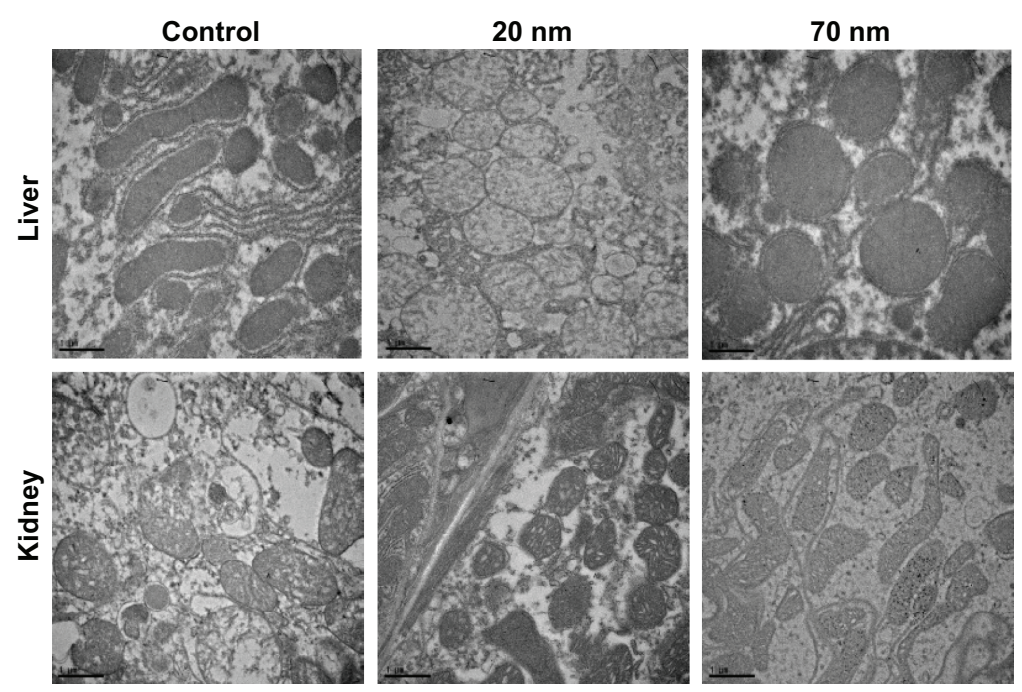

Figure 5 TEM images of the liver and kidney collected 24 hours after oral administration with two different-sized ZnO nanoparticles.

The two $\mathrm{ZnO}$ nanoparticles of different sizes could be easily distinguished from one to another, validating the particle sizes of samples selected for the study.

Body weight change, mortality, behavior, and symptoms were observed after single-dose oral administration for 14 days, and no mortality was found in any of the treated groups. Moreover, no significant body weight loss or symptoms were observed in any of the rats receiving up to $300 \mathrm{mg} / \mathrm{kg}$ of $20 \mathrm{~nm}$ or $70 \mathrm{~nm} \mathrm{ZnO}$ nanoparticles, indicating their low in vivo toxicity. In some cases, slight body weight loss was observed in rats
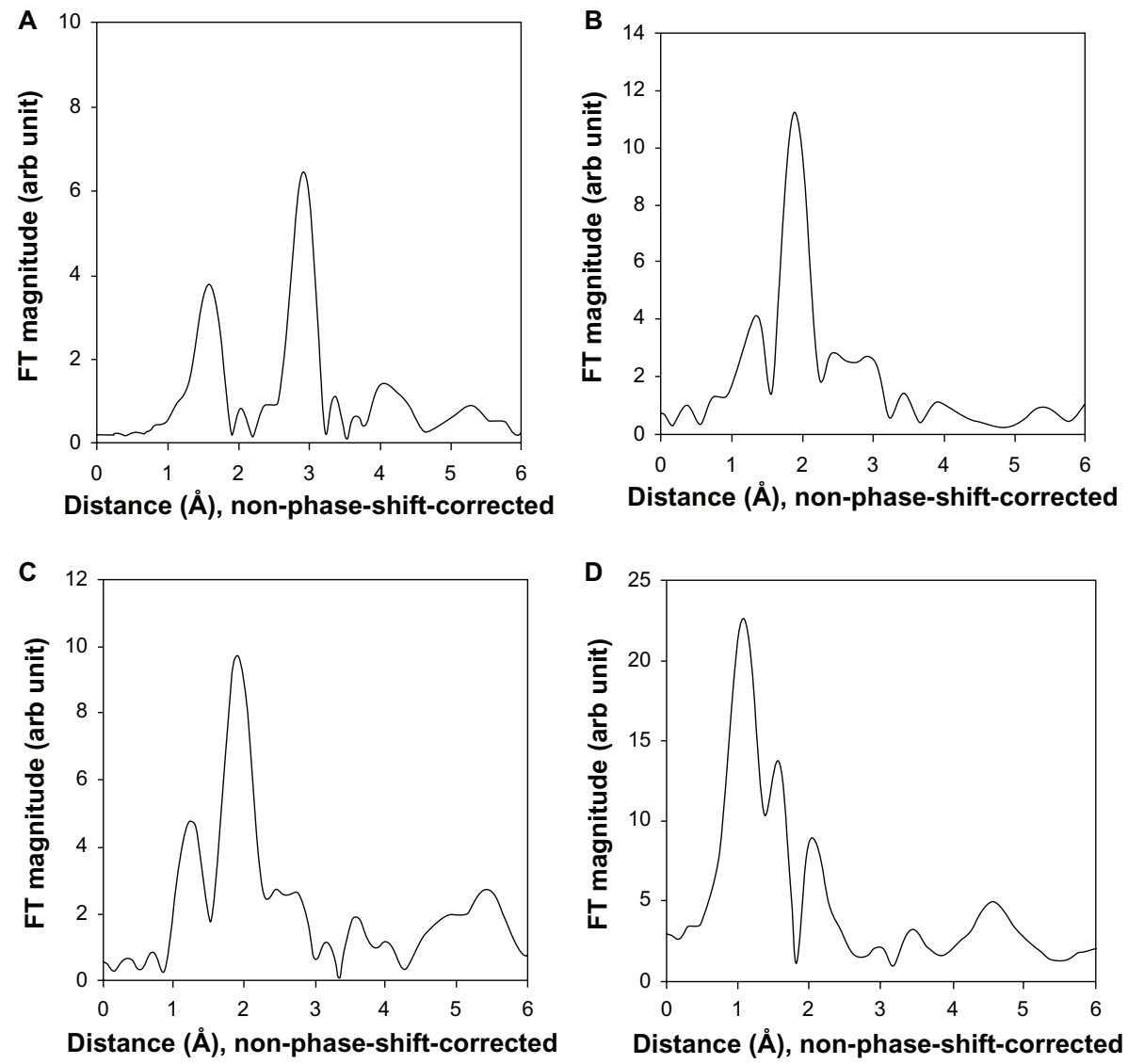

Figure 6 Fourier transform XAS spectra (radial distribution function) for $20 \mathrm{~nm} \mathrm{ZnO}$ nanoparticles before oral administration (A), and liver (B), kidney (C), and spleen (D) at 24 hours after oral administration. 

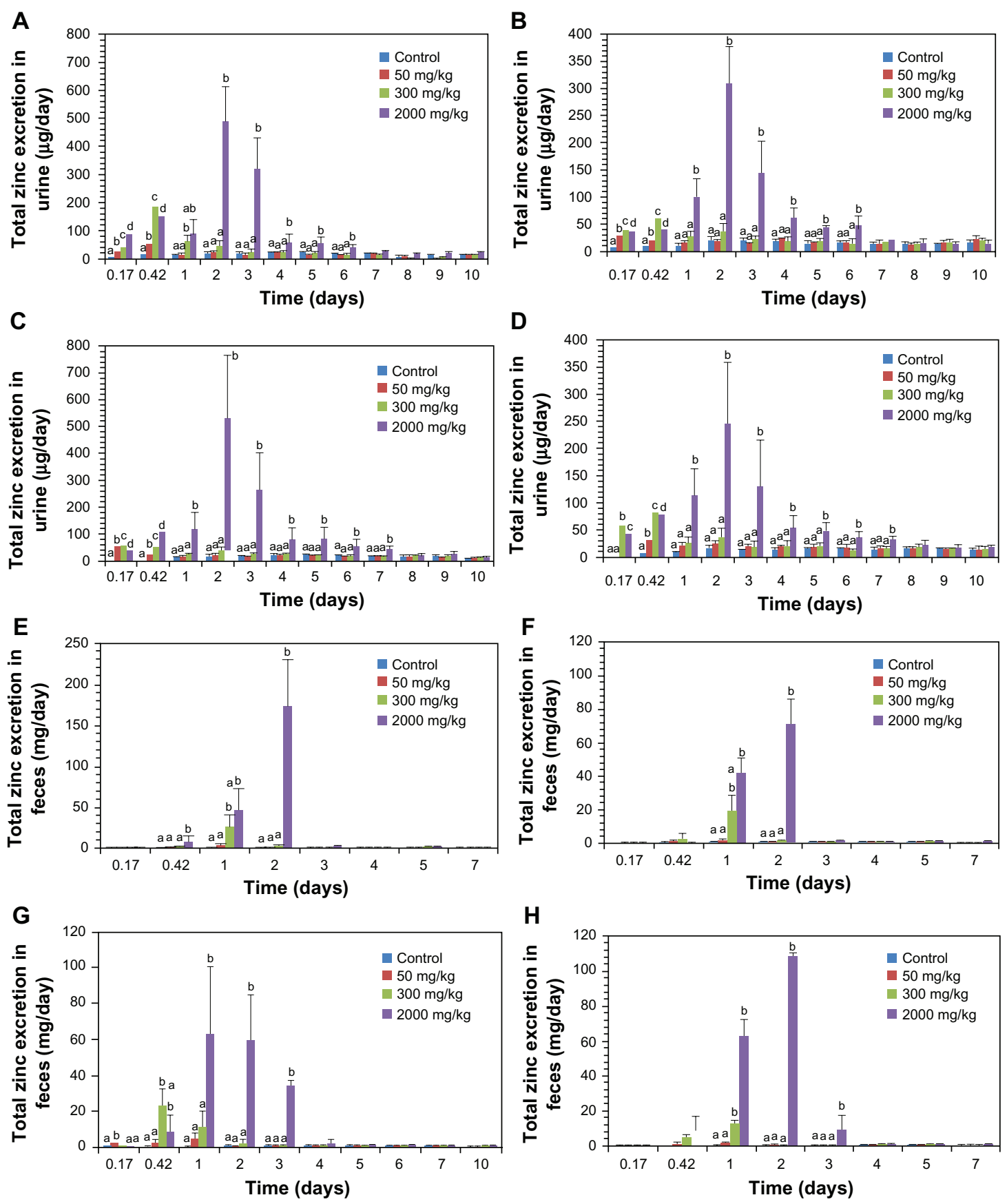

Figure 7 Excretion profile of 20 and $70 \mathrm{~nm} \mathrm{ZnO}$ nanoparticles via urine and feces; $20 \mathrm{~nm}$ and $70 \mathrm{~nm} \mathrm{ZnO}$ nanoparticles in urine in male (A and $\mathbf{C}$ ) and female (B and $\mathbf{D}$ ) rats, respectively; $20 \mathrm{~nm}$ and $70 \mathrm{~nm} \mathrm{ZnO}$ nanoparticles in feces in male (E and $\mathbf{G})$ and female $(\mathbf{F}$ and $\mathbf{H})$, respectively.

administered the $2000 \mathrm{mg} / \mathrm{kg}$ dose of $\mathrm{ZnO}$ nanoparticles, but this did not reach statistical significance. Therefore, it seems that the two different sized $\mathrm{ZnO}$ nanoparticles did not cause any serious oral toxicity after single-dose administration.

After oral administration, a rapid decrease in the plasma zinc concentration over 6 hours was noted in rats receiving the $50 \mathrm{mg} / \mathrm{kg}$ dose, but the plasma zinc level in rats treated with the $300 \mathrm{mg} / \mathrm{kg}$ and $2000 \mathrm{mg} / \mathrm{kg}$ doses gradually decreased within 24 and 72 hours, respectively, indicating that high-dose $\mathrm{ZnO}$ nanoparticles were slowly distributed to the tissues. This result also suggests that the $2000 \mathrm{mg} / \mathrm{kg}$ dose could be retained for longer in the body than the lower doses, as indicated by MRT and $\mathrm{T}_{1 / 2}$ values (Table 2 ). Thus, dose is an important factor influencing absorption, tissue distribution, and residence time. In terms of gender differences, both sizes of $\mathrm{ZnO}$ nanoparticles seemed to be slightly better absorbed in male rats than in female rats (Table 3). In addition, small particles in the order of $20 \mathrm{~nm}$ were likely 
Table 5 Excretion values of different-sized $\mathrm{ZnO}$ nanoparticles via urine and feces in rats

\begin{tabular}{|c|c|c|c|c|c|c|c|c|c|c|c|c|}
\hline & \multicolumn{4}{|c|}{$50 \mathrm{mg} / \mathrm{kg}$} & \multicolumn{4}{|c|}{$300 \mathrm{mg} / \mathrm{kg}$} & \multicolumn{4}{|c|}{$2000 \mathrm{mg} / \mathrm{kg}$} \\
\hline & \multicolumn{2}{|c|}{$20 \mathrm{~nm}$} & \multicolumn{2}{|c|}{$70 \mathrm{~nm}$} & \multicolumn{2}{|c|}{$20 \mathrm{~nm}$} & \multicolumn{2}{|c|}{$70 \mathrm{~nm}$} & \multicolumn{2}{|l|}{$20 \mathrm{~nm}$} & \multicolumn{2}{|l|}{$70 \mathrm{~nm}$} \\
\hline & Male & Female & Male & Female & Male & Female & Male & Female & Male & Female & Male & Female \\
\hline Excretion via urine (\%) & 1.13 & 0.98 & 1.47 & 1.36 & 0.78 & 0.61 & 0.71 & 0.61 & 0.49 & 0.32 & 0.50 & 0.34 \\
\hline Excretion amount via urine (mg) & 0.07 & 0.05 & 0.09 & 0.07 & 0.28 & 0.19 & 0.26 & 0.19 & 1.18 & 0.67 & 1.20 & 0.71 \\
\hline Excretion via feces (\%) & 59.75 & 48.55 & 58.67 & 51.66 & 78.54 & 68.07 & 76.85 & 72.95 & 94.67 & 96.91 & 95.85 & 97.12 \\
\hline Excretion amount via feces (mg) & 3.59 & 2.52 & 3.52 & 2.69 & 28.27 & 21.24 & 27.67 & 22.76 & 227.21 & 201.57 & 230.04 & 202.01 \\
\hline
\end{tabular}

to reach the circulation more easily than the $70 \mathrm{~nm}$ particles (Table 3). Absorption for the $20 \mathrm{~nm}$ and $70 \mathrm{~nm} \mathrm{ZnO} \mathrm{nano-}$ particles was in the range of $6.48 \%-32.49 \%$. The capacity of the body to absorb $\mathrm{ZnO}$ nanoparticles may be limited because absorption of approximately $30 \%$ appeared to be maximal regardless of gender or particle size when the high dose of $2000 \mathrm{mg} / \mathrm{kg}$ was administered. This is probably due to the fact that the uptake of zinc is controlled by specific receptors such as metal-binding proteins, as explained in XAS study session.

The plasma concentration-time curve is consistent with the tissue distribution profile for both particle sizes. As shown in Supplementary Figure 1, significantly increased zinc levels were detected in the rat kidney, liver, and lung within 6 hours of administration for the $50 \mathrm{mg} / \mathrm{kg}$ dose, followed by a decrease in zinc levels, suggesting that a low dose of $\mathrm{ZnO}$ nanoparticles is rapidly distributed to the organs and does not accumulate in these tissues. When the medium $300 \mathrm{mg} / \mathrm{kg}$ dose was administered, zinc levels increased in the kidney, liver, and lung within 6-24 hours, but returned to normal 24 hours after administration (Supplementary Figure 1), indicating pharmacokinetic behavior quite similar to that of the low dose of $50 \mathrm{mg} / \mathrm{kg}$. On the other hand, the tissue distribution kinetic profile of the low dose was found to be different from that in rats given the $2000 \mathrm{mg} / \mathrm{kg}$ dose. As shown in Figure 4, zinc levels were highest in the lung, liver, and kidney at 24 hours and at 2 and 3 days, respectively, following oral administration, without any apparent effect of particle size. Therefore, the results can be summarized as follows. No statistically significant difference in tissue distribution was found between the groups treated with $20 \mathrm{~nm}$ and $70 \mathrm{~nm} \mathrm{ZnO}$ nanoparticles, although the $70 \mathrm{~nm}$ particles seemed to accumulate more and be retained for longer in the lung than were the $20 \mathrm{~nm}$ particles (Table 4). The kidney, liver, and lung would be the possible target organs for accumulation of $\mathrm{ZnO}$ nanoparticles in the cases of the two different sizes, ie, $20 \mathrm{~nm}$ and $70 \mathrm{~nm}$. Also, an increased zinc level in the kidney indicates that the renal pathway might play a role in their clearance. $\mathrm{ZnO}$ nanoparticles were detected in the reproductive organs only one hour after administration, but not found afterwards, so their toxicity in the ovary and testis seems to be low. The zinc level in all organs from male rats was found to be slightly higher than that in the organs from female rats (Table 4), which is consistent with the plasma concentration-time curve (Figure 3) and AUC values (Table 2). However, no statistically significant gender difference in tissue distribution was seen, indicating that there is no gender effect of $\mathrm{ZnO}$ nanoparticles in terms of absorption and distribution. It is important to note that the zinc level in all the organs decreased to normal levels, 7 days after administration. Furthermore, $\mathrm{ZnO}$ nanoparticles were not detected in the gastrointestinal system after the same observation period, suggesting that even a $2000 \mathrm{mg} / \mathrm{kg}$ dose of $\mathrm{ZnO}$ nanoparticles does not accumulate in any specific tissue after 7 days.

Most tissue distribution studies of other nanoparticles have demonstrated that nanoparticles are distributed to the liver and spleen. For example, the tissue distribution of silver nanoparticles after intravenous injection was recently shown to occur in a size-dependent manner, with $20 \mathrm{~nm}$ particles distributed primarily to the liver, followed by the kidney and spleen, whereas those with $80 \mathrm{~nm}$ and $110 \mathrm{~nm}$ were mainly found in the spleen, followed by the liver and lung. ${ }^{25}$ PEG-coated gold nanoparticles $5 \mathrm{~nm}$ and $10 \mathrm{~nm}$ in size accumulated in the liver, but $30 \mathrm{~nm}$ particles were distributed in the spleen after intraperitoneal injection. ${ }^{26} \mathrm{Mag}$ netic iron oxide nanoparticles are also distributed to the liver and spleen after intragastric administration. ${ }^{27}$ For titanium dioxide with a rutile-type structure, particles $20 \mathrm{~nm}$ in size accumulate mainly in the liver and spleen after intravenous injection. ${ }^{28}$ Fluorescence dye-labeled silica nanoparticles have also been reported to become trapped in the liver and spleen in a size-dependent manner. ${ }^{29}$ Both mesoporous silica and PEGylated silica nanoparticles of different particle sizes $(80-360 \mathrm{~nm})$ were also found to be distributed mainly in the liver and spleen. ${ }^{30}$ Summarizing all these findings, it seems likely that phagocytosis by macrophages occurring actively in these two organs plays an important role in the 
uptake of these nanoparticles in vivo. However, the fact that $\mathrm{ZnO}$ nanoparticles were detected in the liver, lung, and kidney, but not in the spleen, suggests that the macrophage is not the only entry route for $\mathrm{ZnO}$ nanoparticles into the tissues. This is likely to be closely related to the ionization properties of $\mathrm{ZnO}$ nanoparticles following oral administration as observed by TEM (Figure 5) and XAS (Figure 6), which showed no $\mathrm{ZnO}$-like nanoparticles and formation of new $\mathrm{Zn}-\mathrm{S}$ bonds, respectively, in the tissues. It has been reported that citrate-coated silver nanoparticles accumulate mainly in the liver, lung, and kidney after intravenous injection, which is consistent with our results. ${ }^{31}$ Even with oral administration, silver nanoparticles accumulate mostly in the liver and kidney after 28 days of repeated oral exposure. ${ }^{32}$ The tendency of $\mathrm{ZnO}$ nanoparticles to distribute in tissue in a manner similar to that of silver nanoparticles might be associated with the enhanced dissolution of nanoparticles, thereby forming metal ions in a living system. ${ }^{33}$ According to radioactive $\mathrm{ZnO}$ experiments, nanoparticles primarily showed retention in the lung, followed by retention in the liver and kidney after intravenous administration, ${ }^{34}$ which again is very consistent with our results.

Given that zinc oxide is rather soluble in neutral and weakly acidic conditions (Supplementary Figure S2), it would be expected that orally administered $\mathrm{ZnO}$ nanoparticles are readily dissolved under gastric conditions, producing zinc cations. Although the dissolved amount of $\mathrm{ZnO}$ nanoparticles depends on experimental conditions such as particle size, specific surface area, dose, and retention time in the stomach or intestine, $\mathrm{ZnO}$ nanoparticles to a certain degree can be expected to dissolve during the digestion process. On the other hand, it has also been reported that particulate uptake in the intestinal tract can be mediated by $\mathrm{M}$ cells (specialized phagocytic enterocytes) and normal intestinal enterocytes, ${ }^{35}$ so the possibility of $\mathrm{ZnO}$ particle uptake cannot be excluded. However, $\mathrm{ZnO}$ nanoparticles could not be observed in the TEM images of the liver and kidney (Figure 5), whereas accumulation of $\mathrm{ZnO}$ nanoparticles was evident on ICP-AES analysis (Figure 4), implying an ionized fate in the tissues.

Our XAS results in rats suggest that the $\mathrm{ZnO}$ nanoparticles dissolved into zinc ions after oral administration because all the $\mathrm{Zn}-\mathrm{Zn}$ bonds were not detected in organs such as the liver, kidney, and spleen. If the $\mathrm{ZnO}$ nanoparticle maintains its crystal lattice structure in the organs, the $\mathrm{Zn}-\mathrm{Zn}$ peak should be observed at around $3.0 \AA$ in the radial distribution function (Figure 6). Therefore, it is highly plausible that $\mathrm{ZnO}$ nanoparticles are dissolved in the stomach to form $\mathrm{Zn}^{2+}$ ions given the $\mathrm{pH}$ value in the stomach is acidic enough to dissolve them. New peaks in radial distribution function due to the formation of $\mathrm{Zn}-\mathrm{S}$ bonds could be assigned as zinc-ligand interactions between zinc ions and proteins, such as metallothionein, with sulfur-rich ligands, which is consistent with previous evidence for zinc ions bonding to sulfur in the liver as determined by XAS analysis. ${ }^{36}$ It is generally known that metallothionein, a cysteine-rich metal-binding protein, is assigned a role in zinc absorption and excretion. ${ }^{37}$ The absence of $\mathrm{Zn}-\mathrm{Zn}$ bonds in the radial distribution function clearly indicates that $\mathrm{ZnO}$ nanoparticles with a wurtzite structure are absent in each organ, which is consistent with the TEM studies (Figure 5). It is worth highlighting that a Zn-S peak was also found in spleen tissue treated with $\mathrm{ZnO}$ nanoparticles, whereas no significant accumulation was confirmed in the tissue distribution study (Figure 4 and Supplementary Figure S1). This new result suggests that $\mathrm{Zn}-\mathrm{S}$ interaction plays an important role in the uptake of $\mathrm{ZnO}$ nanoparticles in all tissues, although their increase was not significantly different from that in the control group. Therefore, it can be concluded that orally administered $\mathrm{ZnO}$ nanoparticles are mostly dissolved in the stomach to form $\mathrm{Zn}^{2+}$ ions, and are then taken up in the tissues by interaction between zinc and sulfur-containing ligands in proteins. The role of dissolved zinc ions in the toxicity assessment of $\mathrm{ZnO}$ nanoparticles has already been reported by many researchers, even under cell culture conditions, ${ }^{38-41}$ and support our results.

The excretion kinetics profile for $\mathrm{ZnO}$ nanoparticles showed that only a small amount $(0.32 \%-1.47 \%)$ of the nanoparticles administered were excreted via the urine, and that the majority $(48.55 \%-97.12 \%)$ was excreted directly via feces without any significant gender difference (Table 5). In particular, urinary excretion was still determined to be low at $1.02 \%-13.39 \%$ when the excretion rate was calculated on the basis of the total amount of $\mathrm{ZnO}$ nanoparticles absorbed (AUC values). This finding suggests that not only does fecal excretion play an important role in elimination, but also that biliary excretion may be involved in the clearance of $\mathrm{ZnO}$ nanoparticles from the body when they are administered orally. This result also confirms that a small amount of orally administered $\mathrm{ZnO}$ nanoparticles are absorbed into the body, implying that most of them were not able to be absorbed and were cleared directly from the body. Meanwhile, the amount of $\mathrm{ZnO}$ nanoparticles excreted via the urine was slightly higher in male rats than in female rats (Table 3 ). It has been reported that most orally administered silver nanoparticles are not absorbed in the gastrointestinal tract and are excreted directly via the feces, 
showing extremely low silver levels in the urine, ${ }^{31,32}$ which is in good agreement with our results. It seems that the dissolution property of both $\mathrm{ZnO}$ and silver nanoparticles into ions contributes to the similar pattern of tissue distribution as well as the excretion pathway. On the other hand, the kidney was found to be the main excretion pathway for $20 \mathrm{~nm}$ titanium dioxide nanoparticles rather than fecal excretion. ${ }^{28}$ Rhodamine $\mathrm{B}$ isothiocyanate-labeled silica nanoparticles were found to be cleared via the urine and bile. ${ }^{29}$

In terms of the excretion profiles for the two differentsized $\mathrm{ZnO}$ nanoparticles, the $20 \mathrm{~nm}$ particles were cleared through the urine and feces over 6 and 2 days, respectively, while excretion of the $70 \mathrm{~nm}$ particles via urine and feces continued for 7 and 3 days, respectively, suggesting that the small $\mathrm{ZnO}$ nanoparticles tend to be more rapidly cleared than the larger ones. A difference in clearance profile depending on particle size has been reported elsewhere, ie, $50 \mathrm{~nm}$ fluorescently labeled silica nanoparticles were reported to be excreted more rapidly via the urine and feces than were $100 \mathrm{~nm}$ and $200 \mathrm{~nm}$ particles. ${ }^{29}$ Based on our findings and previous results reported in the literature, the size-dependent elimination kinetics of these particles is closely associated with the nanosize effect, such as high dissolution, large surface area, and high reactivity.

\section{Conclusion}

The $20 \mathrm{~nm}$ and $70 \mathrm{~nm}$ citrated-capped $\mathrm{ZnO}$ nanoparticles used in this study were not easily absorbed into the bloodstream via the gastrointestinal tract after single-dose oral administration. A tissue distribution study showed accumulation of both sizes of $\mathrm{ZnO}$ nanoparticles in the liver, lung, and kidney, without any statistically significant association with gender or particle size, even when a high dose of $2000 \mathrm{mg} / \mathrm{kg}$ was administered. According to our TEM and XAS studies in tissues following oral administration, $\mathrm{ZnO}$ nanoparticles appear to be absorbed into organs in the form of zinc ions rather than in particulate form as a result of forming new Zn-S bonds, suggesting not only a role of interaction between zinc ions and sulfur-containing ligands in their absorption, but also a toxic potential of zinc ions when administered in large doses. The nanoparticles used in this study were excreted mainly via the feces, suggesting the possibility of biliary excretion, and smaller particles were cleared more rapidly than larger ones. $\mathrm{ZnO}$ nanoparticle doses below $300 \mathrm{mg} / \mathrm{kg}$ were distributed in the tissues and excreted within 24 hours, implying low toxicity. These findings provide crucial information for estimating the potential acute and chronic toxicity of $\mathrm{ZnO}$ nanoparticles in likely target organs.

\section{Acknowledgment}

This research was supported by a grant (10182 KFDA991)

from the Korea Food and Drug Administration in 2010.

\section{Disclosure}

The authors report no conflicts of interest in this work.

\section{References}

1. Djurisic $\mathrm{AB}$, Leung YH. Optical properties of $\mathrm{ZnO}$ nanostructures. Small. 2006;2:944-961.

2. De Berardis B, Civitelli G, Condello M, et al. Exposure to $\mathrm{ZnO}$ nanoparticles induces oxidative stress and cytotoxicity in human colon carcinoma cells. Toxicol Appl Pharmacol. 2010;246:116-127.

3. Fan Z, Lu JG. Zinc oxide nanostructures: synthesis and properties. J Nanosci Nanotechnol. 2005;5:1561-1573.

4. Qian JL. The surface properties and photocatalytic activities of $\mathrm{ZnO}$ ultrafine particles. Appl Surf Sci. 2011;180:308-314.

5. Su YK, Peng SM, Ji LW, et al. Ultraviolet $\mathrm{ZnO}$ nanorod photosensors. Langmuir. 2009;26:603-606.

6. Kumari L, Li WZ. Synthesis, structure and optical properties of zinc oxide hexagonal microprisms. Cryst Res Technol. 2010;45:311-315.

7. Baek M, Kim MK, Cho HJ, et al. Factors influencing the cytotoxicity of zinc oxide nanoparticles: particle size and surface charge. $J$ Phys Conf Ser. 2011;304:012044.

8. Sokohara S, Ishida M. Visible luminescence and surface properties of nanosized $\mathrm{ZnO}$ colloids prepared by hydrolyzing zinc acetate. $J$ Phys Chem B. 1998;102:10169-10175.

9. Wang B, Feng W, Wang M, et al. Acute toxicological impact of nano- and submicro-scaled zinc oxide powder on healthy adult mice. J Nanopart Res. 2008;10:263-276.

10. Oberdorster G, Oberdorster E, Oberdorster J. Nanotoxicology: an emerging discipline evolving from studies of ultrafine particles. Environ Health Perspect. 2005;113:823-839.

11. Hillyer JF, Albrecht RM. Gastrointestinal persorption and tissue distribution of differently sized colloidal gold nanoparticles. J Pharm Sci. 2001;90:1927-1936.

12. Pasupuleti S, Alapati S, Ganapathy S, et al. Toxicity of zinc oxide nanoparticles through oral route. Toxicol Ind Health. October 27, 2011. [Epub ahead of print.]

13. Wang B, Feng WY, Wang TC, et al. Acute toxicity of nano- and micro-scale zinc powder in healthy adult mice. Toxicol Lett. 2006;161: 115-123.

14. Fabian E, Landsiedel R, Ma-Hock L, et al. Tissue distribution and toxicity of intravenously administered titanium dioxide nanoparticles in rats. Arch Toxicol. 2008;82:151-157.

15. Kim YS, Kim JS, Cho HS, et al. Twenty-eight-day oral toxicity, genotoxicity, and gender-related tissue distribution of silver nanoparticles in Sprague-Dawley rats. Inhal Toxicol. 2008;20:575-583.

16. Li SD, Huang L. Pharmacokinetics and biodistribution of nanoparticles. Mol Pharm. 2008;5:496-504.

17. Choi SJ, H CJ. Effect of physico-chemical parameters on the toxicity of inorganic nanoparticles. J Mater Chem. 2011;21:5547-5554.

18. Nair S, Sasidharan A, Divya Rani VV, et al. Role of size scale of ZnO nanoparticles and microparticles on toxicity toward bacteria and osteoblast cancer cells. J Mater Sci Mater Med. 2009;20:S235-S241.

19. Moos PJ, Chung K, Woessner D, et al. ZnO particulate matter requires cell contact for toxicity in human colon cancer cells. Chem Res Toxicol. 2010;23:733-739.

20. Lin $\mathrm{W}, \mathrm{Xu}$ Y, Huang CC, et al. Toxicity of nano- and micro-sized $\mathrm{ZnO}$ particles in human lung epithelial cells. J Nanopart Res. 2009;11: 25-39.

21. Paek SM, Jung H, Park M, et al. An inorganic nanohybrid with high specific surface area: TiO2-pillare MoS2. Chem Mater. 2005; 17:3492-3498. 
22. Leeuwenburgh SC, Ana ID, Jansen JA. Sodium citrate as an effective dispersant for the synthesis of inorganic-organic composites with a nanodispersed mineral phase. Acta Biomater. 2010;6:836-844.

23. Parkinson JA, Sun H. New approach to the solution chemistry of bismuth citrate antiulcer complexes. Chem Commun. 1998;8:881-882.

24. Xu X, Wang ZL. One-dimensional ZnO nanostructures: solution growth and functional properties. Nano Res. 2011;4:1013-1098.

25. Lankveld DP, Oomen AG, Krystek P, et al. The kinetics of the tissue distribution of silver nanoparticles of different sizes. Biomaterials. 2010;31:8350-8361.

26. Zhang XD, Wu D, Shen X, et al. Size-dependent in vivo toxicity of PEGcoated gold nanoparticles. Int J Nanomedicine. 2011;6:2071-2081.

27. Wang J, Chen Y, Chen B, et al. Pharmacokinetic parameters and tissue distribution of magnetic $\mathrm{Fe}(3) \mathrm{O}(4)$ nanoparticles in mice. Int $J$ Nanomedicine. 2010;5:861-866.

28. Xie G, Wang C, Sun J, Zhong G. Tissue distribution and excretion of intravenously administered titanium dioxide nanoparticles. Toxicol Lett. 2011;205:55-61.

29. Cho M, Cho WS, Choi M, et al. The impact of size on tissue distribution and elimination by single intravenous injection of silica nanoparticles. Toxicol Lett. 2009;189:177-183.

30. He Q, Zhang Z, Gao F, et al. In vivo biodistribution and urinary excretion of mesoporous silica nanoparticles: effects of particle size and PEGylation. Small. 2011;7:271-280.

31. Park K, Park EJ, Chun IK, et al. Bioavailability and toxicokinetics of citrate-coated silver nanoparticles in rats. Arch Pharm Res. 2011;34: 153-158.
32. Loeschner K, Hadrup N, Qvortrup K, et al. Distribution of silver in rats following 28 days of repeated oral exposure to silver nanoparticles or silver acetate. Part Fibre Toxicol. 2011;8:18.

33. Lubick N. Nanosilver toxicity: ions, nanoparticles - or both? Environ Sci Technol. 2008;42:8617.

34. Chen JK, Shih MH, Peir JJ, et al. The use of radioactive zinc oxide nanoparticles in determination of their tissue concentrations following intravenous administration in mice. Analyst. 2010;135:1742-1746.

35. Hussain N, Jaitley V, Florence AT. Recent advances in the understanding of uptake of microparticulates across the gastrointestinal lymphatics. Adv Drug Deliv Rev. 2001;50:107-142.

36. Beauchemin S, Hesterberg D, Nadeau J, et al. Speciation of hepatic $\mathrm{Zn}$ in trout exposed to elevated waterborne $\mathrm{Zn}$ using X-ray absorption spectroscopy. Environ Sci Technol. 2004;38:1288-1295.

37. Starcher BC, Glauber JG, Madaras JG. Zinc absorption and its relationship to intestinal metallothionein. J Nutr. 1980;110:1391-1397.

38. Song W, Zhang J, Guo J, et al. Role of the dissolved zinc ion and reactive oxygen species in cytotoxicity of $\mathrm{ZnO}$ nanoparticles. Toxicol Lett. 2010;199:389-397.

39. Brunner TJ, Wick P, Manser P, et al. In vitro cytotoxicity of oxide nanoparticles: comparison to asbestos, silica, and the effect of particle solubility. Environ Sci Technol. 2006;40:4374-4381.

40. Xia T, Kovochich M, Liong M, et al. Comparison of the mechanism of toxicity of zinc oxide and cerium oxide nanoparticles based on dissolution and oxidative stress properties. ACS Nano. 2008;2:2121-2134.

41. Deng X, Luan Q, Chen W, et al. Nanosized zinc oxide particles induce neural stem cell apoptosis. Nanotechnology. 2009;20:115101. 


\section{Supplementary figures}
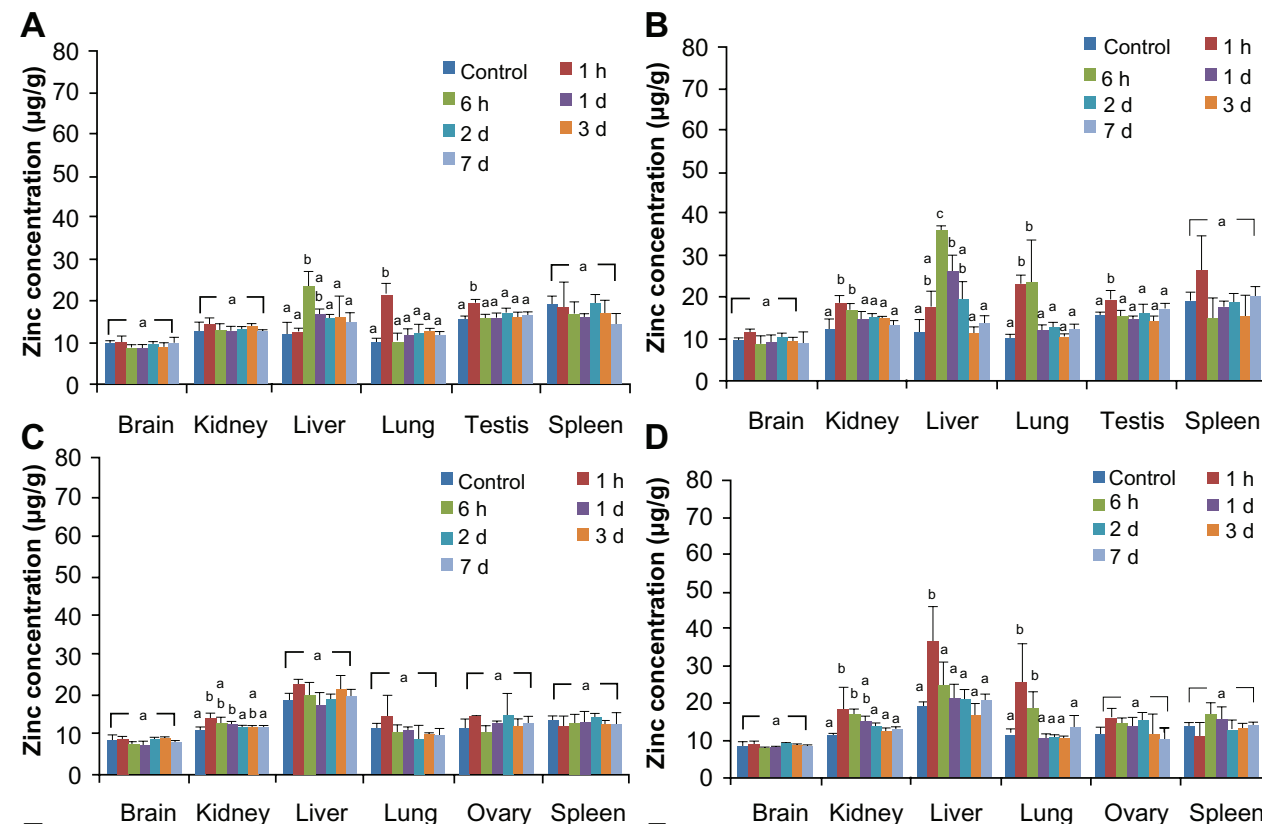

D Brain Kidney Liver Lung Testis Spleen

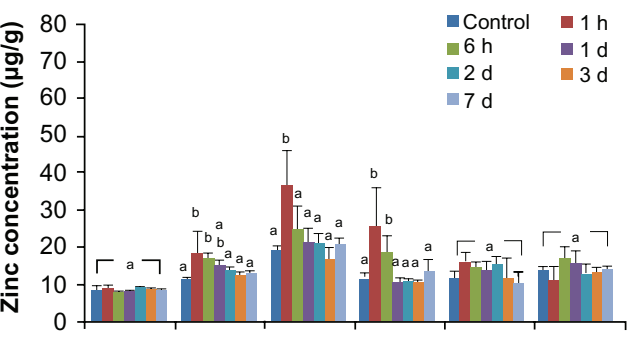

E
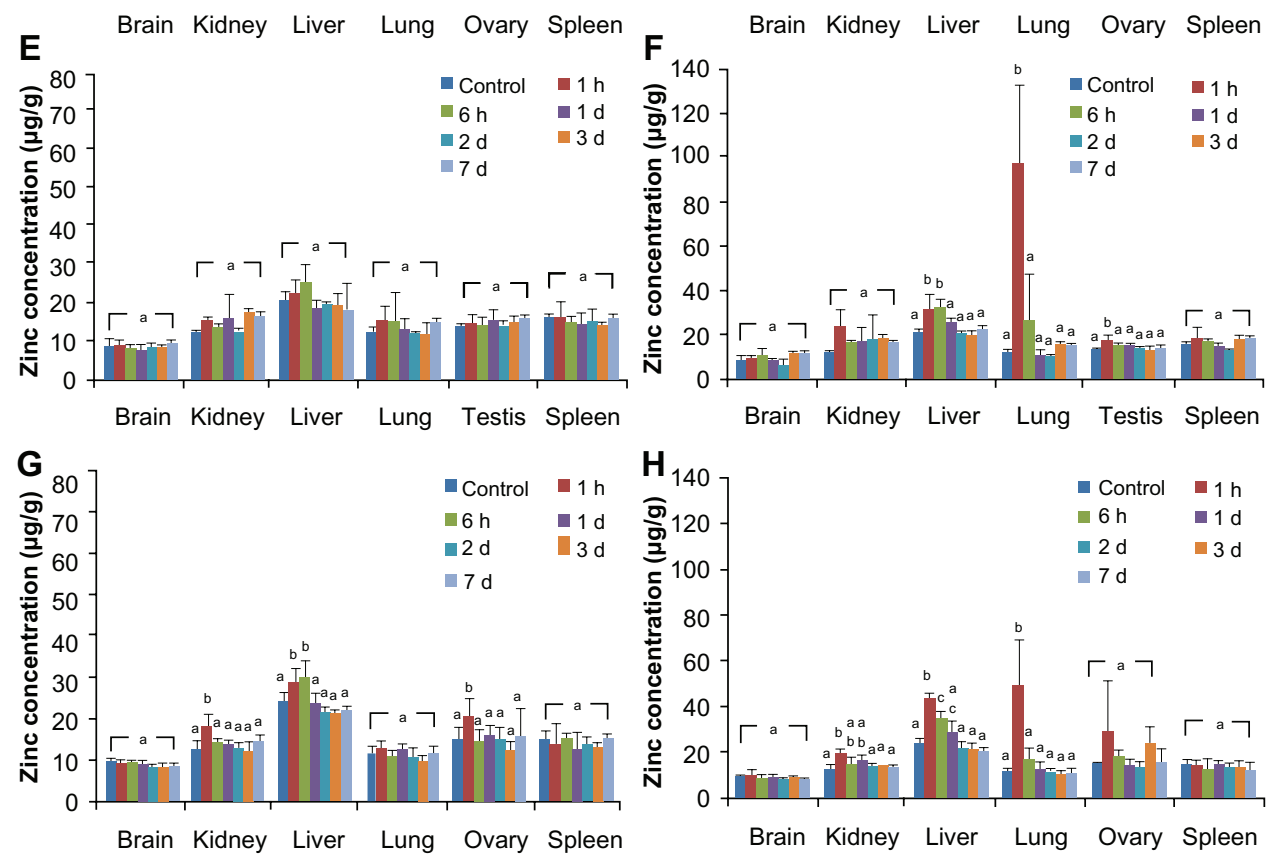

Figure SI Tissue distribution of ZnO nanoparticles in rats after single dose oral administration of $50 \mathrm{mg} / \mathrm{kg}$ and $300 \mathrm{mg} / \mathrm{kg} .50 \mathrm{mg} / \mathrm{kg}$ and $300 \mathrm{mg}$ of $20 \mathrm{~nm}$ in male (A and B) and female (C and D). $50 \mathrm{mg} / \mathrm{kg}$ and $300 \mathrm{mg}$ of $70 \mathrm{~nm}$ in male (E and $\mathbf{F})$ and female $(\mathbf{G}$ and $\mathbf{H})$ rats, respectively. 


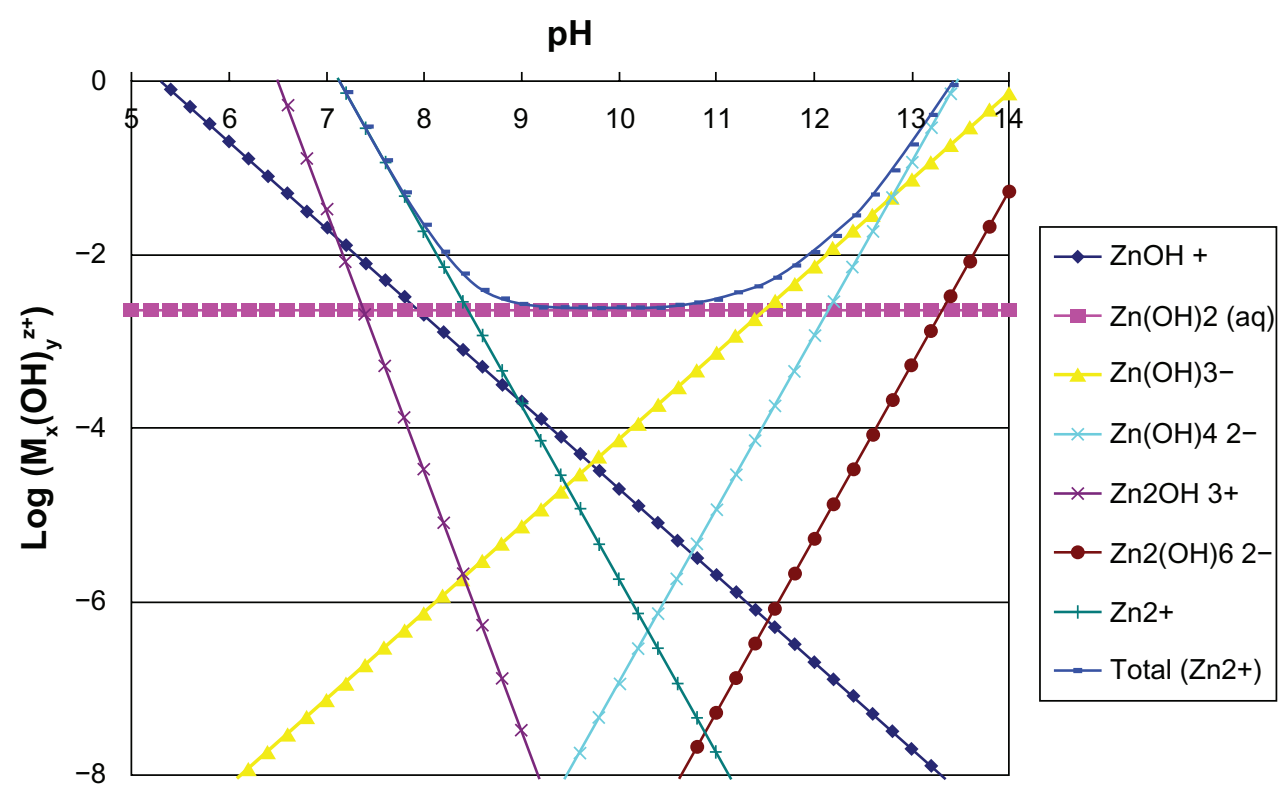

Figure $\mathbf{S 2}$ Solubility diagram of zinc cations in aqueous solution with respect to $\mathrm{pH}$.

\section{Publish your work in this journal}

The International Journal of Nanomedicine is an international, peerreviewed journal focusing on the application of nanotechnology in diagnostics, therapeutics, and drug delivery systems throughout the biomedical field. This journal is indexed on PubMed Central, MedLine, CAS, SciSearch ${ }^{\circledR}$, Current Contents ${ }^{\circledR} /$ Clinical Medicine,
Journal Citation Reports/Science Edition, EMBase, Scopus and the Elsevier Bibliographic databases. The manuscript management system is completely online and includes a very quick and fair peer-review system, which is all easy to use. Visit http://www.dovepress.com/ testimonials.php to read real quotes from published authors.

\footnotetext{
Submit your manuscript here: http://www.dovepress.com/international-journal-of-nanomedicine-journal
} 